\title{
ORTA ÇAĞ'DA BİR KALE ŞEHİR: RAHBE VE TARİHİ
}

\begin{abstract}
Ahmet Kütük*
$\ddot{O} z$

Erken İslam döneminde bir istihkâm şehri olarak kurulmuş olup günümüze sadece harabeleri intikal etmiş bulunan çok sayılda yerleşim vardır. Bunlar arasında bugün Suriye sinırları içinde bulunan Rahbe, Orta Çağ kaynaklarında adı sıkça telaffuz edilen önemli kale şehirlerden biridir. Rahbe, Fırat kenarına yerleșen stratejik konumu ve özellikle çift duvarla örülmüş korunaklı kalesiyle 9. asırda Müslümanlar eliyle kurulduğu ilk dönemlerden itibaren Irak'tan batıya yapılacak seferler için önemli bir istinat noktası teşkil ettiğinden birçok hükümdar tarafindan kıskançlıkla istenen bir şehir olmuştur. 12. yüzyıldan itibaren Haçlıların; 13. yüzyıldan sonra da Moğolların bölgeye gelmeleriyle bir kale-şehir sıfatıyla daha fazla önem kazanan Rahbe, bu yüzyıllarda yaşanan iktidar mücadeleleri neticesinde çok sayıda yerel yönetici arasında sıklıkla el değiştirmiştir. Osmanlı hâkimiyeti sonrası eski önemini yitiren şehir, günümüzde sadece kaleye ait harabeleri kalmış bir yerleşimdir. $\mathrm{Bu}$ makalede muhtelif Orta Çă̆ kaynakları ışığında Rahbe şehrinin kuruluşu, tarihi coğrafyası, siyasi, coğrafi, iktisadi, içtimai ve mimari durumuyla ilgili bilgiler verilmeye çalışlacaktır.
\end{abstract}

Anahtar Kelimeler: Rahbe, Mâlik b. Tavk, Meyadin, Suriye, Moğollar, Memlükler.

\section{A Fortress City in the Middle Ages: Rahba and its History}

\begin{abstract}
At the present time there are many settlements which founded as a fortification city in the early Islamic period that only ruins survived. Among these Rahba, which is located within the borders of Syria today, is one of the important castle cities whose name is frequently mentioned in the medieval sources. Due to its strategic position on the banks of the Euphrates and especially with its sheltered castle built with double walls, Rahba became a city enviously desired by many rulers from the first period when it was founded by Muslims in the $9^{\text {th }}$ century. Rahba gained more importance as a castle-city after the Crusaders and Mongols came to this region in the $12^{\text {th }}$ and $13^{\text {th }}$ centuries. It has frequently changed owners among many local
\end{abstract}

* Doç.Dr., Mardin Artuklu Üniversitesi, Edebiyat Fakültesi, Tarih Bölümü, Kampüs Yerleşkesi, Diyarbakır Yolu 5. Km, 47100, Artuklu-Mardin/Türkiye, ahmetkutuk@artuklu.edu.tr, Orcid ID: 0000-0002-0092-5447. 
rulers as a result of the power struggles. The city, which lost its previous importance after the Ottoman domination, is a settlement that has only ruins belonging to the castle. In this article will be given information about the foundation of Rahba, its historical geography, political, geographical, economic, social and architectural situation in the consideration of various medieval sources.

Keywords: Rahba, Mâlek b. Tawk, al-Miyadin, Syria, Mongols, Mamluks.

\section{Giriş: Şehrin Kuruluşu, Coğrafî Konumu ve Adının Etimolojisi}

Halep, Dımaşk, Rakka gibi önemli şehirlerin yer aldığı Suriye coğrafyasında Orta Çă̆ kaynaklarında sıkça bahsedilen, bugün önemli ölçüde adı unutulmuş kritik bir şehir daha bulunuyordu. Kaynaklarda Rahbe [رحبة]), Rahbetü Mâlik b. Tavk رحبة مالك بن طوق] veya Rahbetü’ş-Şâm [رحبة الثام] adlarıyla anılan bu yerleşim, Firat Nehri kıyısında kurulmuş en büyük şehirlerden biri olarak ${ }^{1}$ Irak ile Suriye topraklarını birbirinden ayıran bir sınır-istihkam kenti vazifesi görüyor, bu pozisyonuyla Irak'tan Suriye'ye geçişin anahtar şehri olarak görülüyordu. Orta Çă̆ kaynaklarında 9. ve 15. yüzyıllar arasında adından sıkça bahsedilen ${ }^{2}$ şehrin yerleştiği coğrafi sahanın İslam fetihlerinden önceki durumu hakkında neredeyse hiçbir malumat yoktur. Yalnızca bazı kaynaklarda Tevrat'ta geçen Rebobot han-Nahar'in (Firat'in kiyısındaki Rehobot) bilinen Rahbe ile aynı olduğu varsayılmıştır. ${ }^{3}$ Bunun dışında Taberî (ö. 923) bir vesileyle şehrin eski adından Furzat Num veya yalnızca Furzat olarak bahsetmiştir. ${ }^{4}$ Diğer kaynaklarda geçmeyen bu ihtimaller bir tarafa bırakılırsa şehrin kuruluşuyla ilgili bilgi veren yazılı kaynaklar Rahbe'nin, Abbasî halifesi el-Me'mun (813-833) zamanında Mâlik b. Tavk et-Tağlibî adında bir

1 Ibn Serapion, "Description of Mesopotamia And Baghdad", (Arapça Metin, İng. çev. ve Notlar G. Le Strange), Journal of Royal Asiatic Society, London 1895, s. 47; İbn Hurdazbih, Yollar ve Ülkeler Kitabı, (Çev. M. Ağarı), İstanbul 2008, s. 69; İbn Havkal, 10. Asırda İslam Coğrafyası, (Çev. R. Şeşen), İstanbul 2014, s. 175; İbn Cübeyr, Endülüs'ten Kutsal Topraklara, (Çev. İ. Güler), İstanbul 2003, s. 182; Mukaddesî, İslam Coğrafyası, (Ahsenü't-Tekasim), (Çev. A. Batur), İstanbul 2015, s. 145; Ebü'l Fida, Ebü'l Fida Coğrafyası (Takvimü'l Büldan), (Çev. R. Şeşen), İstanbul 2017, s. 61, 231, 237; İbnü’l Esir, el-Kâmil Fi’t Tarih, (Neşr. Dr. M. Yusuf Dekak), c. VI, Beyrut 1987, s. 249, (Türkçe terc. A. Ağırakça, c. VII, s. 228); İbn Haldun, Mukaddime, (Haz. S. Uludağ), c. I, İstanbul 2007, s. 246; Kâtip Çelebi, Cihânnümâ, (Ed. S. Öztürk), İstanbul 2010, s. 533.

2 Thierry Bianquis, "Raḥba Et Les Tribus Arabes Avant Les Croisades", Bulletin D'études Orientales, Institut Francais du Proche-Orient (1989-1990), s. 23.

3 Bkz. The Holy Bible, An Extract Reprint Page for Page of the Authorized Version, Oxford University Press., Oxford 1833, (Genesis, X: 11; XXVI: 22, XXXVI: 37). Ayrica bkz. Francis Rawdon Chesney, Narrative of The Euphrates Expedition, Carried On By Order of The British Government During The Years 1835, 1836 and 1837, London 1868, s. 251; Hormuzd Rassam, Asshur and the Land of Nimrod, New York 1897, s. 333; E. Honigmann, "Rahbe", $\dot{I}$ A, c. IX, İstanbul 1964, s. 601.

4 Bkz. Tabarî, The History of al-Tabari (Ta'rikh al-rusul wa 'l-muluk), (İng. terc. C. E. Bosworth), vol. V, New York 1999, s. 187-188. Ayrica Alois Musil, The Middle Euphrates: A Topographical Itinerary, New York 1927, s. 340; Guy Le Strange, The Lands of Caliphate, New York 1905, s. 107, 125. 
komutan eliyle kurulmuş olduğu noktasında müttefiktir. ${ }^{5}$ Belazurî (ö. 892) şehrin tamamen boş bir arazi üzerinde inşa edildiğinden emindir. ${ }^{6}$ Kelimenin anlamına gelince Rahbe sözcüğü, Yakut el-Hamevî’nin (ö. 1229) sözlüğünde "bir vadinin su toplanan düz yeri”" şeklinde izah edilmiştir. ${ }^{7}$ Muhtemelen bu anlamından hareketle tarihi kaynaklarda şehrin adının manası "meydan" şeklinde açıklanmıştır ki günümüzde antik şehrin yerleştiği bölgeye meydanlar anlamına gelen "el-Meyâdin” [الميادين] ad1 verilmesi yine bu durumla ilişkili olmalıdır. ${ }^{8}$

Rahbe'nin yerleştiği coğrafi saha, kurulduğu andan itibaren onu diğer yerleşimlerden ayıran en önemli özelliği olmuştur. Şehir, Fırat Nehri’nin Irak ve Suriye coğrafyalarını birbirinden ayırdığı bir sahada kurulmuş olup hem Suriye hem de Irak ile ilişkili bir pozisyona sahipti. (Bkz. Resim IV) Ayrıca bir tarafının nehir olması hasebiyle dişarıdan gelecek tehlikelere karşı doğal bir engele sahip bulunuyordu. Müslüman seyyahlar şehri dördüncü iklime dahil edip diğer şehirlerle arasındaki mesafeye dair bilgiler verirler. Buna göre Rahbe, Dimaşk'tan 8, Halep'ten 5, Musul'dan 3 ve Karkisya'dan 1 günlük bir mesafeye yerleşmektedir. Şehri Rakka ile Ane arasına yerleştiren Ebü'l Fida’ya (ö. 1331) göre Karkisya ile Rahbe arasında 3 fersahlık bir mesafe bulunur. ${ }^{9}$ Hamdullah Müstevfî (ö. 1340’tan sonra), Rahbe ile Anbar arasındaki mesafeyi 170 fersah olarak tayin etmekte, yerleşimin Fırat'a uzaklı̆̆ını yaklaşık 2000 adım, şehrin çevresini ise 5500 adım olarak tespit etmektedir. ${ }^{10}$ 17. yüzyıl müellifi Kâtip Çelebi (ö. 1657), Rakka ile Ane arasına yerleşen bu şehrin Harran'dan 2 fersah mesafede bulunduğunu belirtir. ${ }^{11}$ Şemseddin Sami (ö. 1904) ise şehri Fırat hattı üzerinde Karkisya’nın aşağısında

5 el-Belazurî, Fütubu'l Büldan (Ülkelerin Fetibleri), (Çev. M. Fayda), İstanbul 2013, s. 208; Kudâme İbn Cafer, Kitabü'l Harac (Fetibler, Siyaset, Coğrafya, Vergiler ve Bürokrasi), (Çev. R. Şeşen), İstanbul 2018, s. 44; İbn Havkal, s. 190; İbn Cübeyr, s. 182; Ebü’l Fida, s. 237; Ibn Khallikan, Kitab-ı Vefayatu'l Ayan, (Biographical Dictionary), (İng. çev. M. G. De Slane), vol. II, London, 1843, s. 165; Zehebî, Düveliü'l İslam, c. I, (Tahk. H. İsmail Merde), Beyrut 1999, s. 232; İbn Battuta Tancî, İbn Battuta Seyahatnâmesi, (Çev. A. S. Aykut), c. II, İstanbul 2004, s. 921; Kâtip Çelebi, s. 533; Şemseddin Sami, "Rahbetü Mâlik b. Tavk", Kamus al-A'lam, c. III, İstanbul 1308 (1891), s. 2270; Le Strange, s. 105; Eliyahu Ashtor, A Social and Economic History of the Near East in the Middle Ages, London 1976, s. 88; Bianquis, s. 27; Marie-Odile Rousset, "La Ville De Raḥba-Mayādīn Et Sa Région, IX"-XIVe Siècle”, Bulletin d'études orientales, T. 52, (2000), s. 244. Yakut el Hamevî, şehrin kuruluşunu Harun Reşid dönemine atfeden bazı diyaloglar aktarır. Bkz.Yakut el-Hamevî, Mu'cemu'l Buldan, c. III, Beyrut 1977, s. 34-35; Rousset, s. 245.

6 Belazurî, s. 208. Ayrıca bkz. Ernst Herzfeld, Archaologische Reise im Euphrat-und Tigris-Gebiet, vol. II, Berlin 1911, s. 382; Musil, s. 340-341.

7 Yakut, III, s. 34; Le Strange, s. 105; Herzfeld, II, s. 382.

8 Günümüzde Deyrizor şehrinin yaklaşık 45 km güneyindeki Meyadin yerleşimi Rahbe şehrinin eski bakiyelerini de içerisinde barındırmaktadır. Bkz. Herzfeld, II, s. 382; Honigmann, "Rahbe", $\dot{I} A$, IX, s. 603; Rousset, s. 243.

9 Bkz. Tudelalı Benjamin-Ratisbonlu Petechia, Ortaçağda İki Yahudi Seyyahın İslam Dünyası Gözlemleri, (Çev. N. Arslantaş), İstanbul 2009, s. 68; Ebü’l Fida, s. 237; Yakut el-Hamevî, III, s. 34; Musil, s. 344.

10 Hamdallah Mustawfî, Nuzhat-al-Qulub, (İng. çev. G. Le Strange), Leiden 1919, s. 167, 242.

11 Kâtip Çelebi, s. 533. 
Bağdat'tan 100, Rakka'dan yaklaşık 20 fersahlık mesafede bir kasaba olarak tanımlamıştır. ${ }^{12}$

Rahbe şehri, coğrafi pozisyonu itibariyle kurulduğu zamandan itibaren çözülemeyen ve dönemin kaynaklarında yer alan çelişik bilgilerle daha da derinleşen kritik sorularla yüzleşmek zorunda kalmıştır. Şehrin topografyası ve tarihi ile ilgili araştırmalarıyla bilinen çağdaş yazar T. Bianquis, bu noktada iki temel soruya odaklanır. Birincisi şehrin Irak sınırları içinde mi yoksa Suriye sınırları içinde mi kabul edilmesi gerektiğidir. Esasen Rahbe'nin, Irak ile Suriye'yi birbirinden ayıran sınır üzerinde kurulmuş olması Orta Çă̆ seyyahlarının kafasını karıştırmıştır. Mesela 10. yüzyılda kaleme alınan Hududu'l Âlem 'n adı meçhul müellifi ile 14. asır seyyahı İbn Battuta (ö. 1369) şehri hiç tereddüt göstermeden Irak bölgesine dahil etmişlerdir. Battuta, açık ifadelerle Irak coğrafyasının bu şehirle son bulduğunu ve buradan ötesinin Şam [Suriye] olduğunu belirtmiştir. ${ }^{13}$ Buna karşılık Battuta ile aynı asırda yaşayan Hamdullah Müstevfî'ye göre bu şehir Suriye'nin bir parçası olarak görülmelidir. ${ }^{14}$ Aslında vekayinâmelerde şehirle ilgili verilen bilgiler, Rahbe'nin Suriye ülkesine ait bir yerleşim olarak algılandığını gösteriyor. Çağdaş yazar T. Bianquis, bütün ihtimalleri tartsştıktan sonra şehrin Irak’a ulaşmadan önceki son büyük Suriye şehri olduğunu belirtir ve onun tartışmasız Suriye'nin bir parçası olarak görülmesi gerektiğini düşünür. ${ }^{15}$

Rahbe ile ilgili makul cevaplar arayan ikinci kritik soru, şehrin bağlı olduğu hiyerarşi ve bu hiyerarşideki konumuyla alakalıdır. Rahbe, askeri stratejik pozisyonuyla öne çıkan bir sınır güvenlik şehri mi yoksa kırsal yönetimin başşehri midir? Arap coğrafyacıları genellikle ikinci cevaba odaklanmışlar, Rahbe'nin, F1rat'ın Suriye yakasında bedevilerin bozkırlarıla çevrelenen orta büyüklükte bir şehir olduğuna hükmetmişlerdir. ${ }^{16}$ Şehrin, aşağıda bahsedileceği üzere tüm Orta Çağ boyunca bedevi yağmacılar tarafından saldırılara maruz kalmış olması da bu ihtimali güçlü kılmaktadır. Bununla birlikte Suriye ve Irak’1 birbirinden ayıran Fırat hattı üzerindeki konumuyla Rahbe, iç mimarisi ve özellikle çift duvarlarla örülmüş güçlü kalesiyle kurulduğu andan itibaren tüm Orta Çağ devletleri nezdinde bir sinır güvenlik şehri olarak telakki edilmiştir. Rahbe, 11. asrın ortalarından itibaren Fatımî-Abbasî odaklı Sünnî-Şî̀ çatışmasını yakından hisseden stratejik karakol şehirlerden biri olmuş, müteakip asırlarda İlam coğrafyasının merkezine yerleşen konumuyla bu önemini muhafaza etmiştir. Böylece Moğolların Bağdat'ı işgaline kadar (1258) bölgede bitmek bilmeyen çatışmalara yakından tanık olan şehir, bu

12 Şemseddin Sami, "Rahbetü Mâlik b. Tavk", III, s. 2270.

13 Bkz. Minorsky, V. Hududu'l Âlem Mine’l Meşrik İle’l Mağrib, (Çev. A. Duman-M. Ağarı), İstanbul 2008, s. 100; İbn Battuta, II, s. 921.

14 Hamdullah Mustawfi, Nüzhetü'l Kulub, s. 242.

15 Bianquis, s. 26-27.

16 Herzfeld, II, s. 382; Ashtor, s. 159; Bianquis, s. 25. 
tarihten sonra Suriye'de seyreden Moğol-Memlük mücadelesinin şiddetini çok daha derinden hissetmeye başlamıştır. ${ }^{17}$

\section{Şehrin Siyasi Tarihi}

Yukarıda belirtildiği üzere, yazılı kaynaklar Rahbe'nin 9. yüzyıl ortalarına doğru Abbasî komutanlarından Mâlik b. Tavk et-Tağlebî eliyle kurulduğunu belirtmektedirler. Söylendiğine göre Mâlik b. Tavk'ın ölümünden sonra ${ }^{18}$ yerine oğlu Ahmed geçmişse de bu bölgeye hâkim olan İbn Ebi Sac tarafindan şehirden uzaklaştırılmıştır. İbn Ebi Sac'ın, 12 Nisan 883 tarihinde şehri kilıç zoruyla ele geçirmesi üzerine Ahmed buradan ayrılıp Şam’a kaçmıştır. ${ }^{19}$ Bu dönemden itibaren k1sa aralıklarla el değiştiren şehir, h. 291 (903-904) y1lı olayları içinde Kasım b. Sima adlı birinin iktaları arasında görülmektedir. ${ }^{20}$ 10. asır başlarından itibaren korunaklı yapısı Rahbe'yi isyankâr şahıs veya grupların gözde şehri haline sokmuştur. Nitekim bu dönemde Suriye'de aktif olan Karmatî grupların faaliyetleri Rahbe'nin zaman zaman yağma ve tahriplere maruz kalmasıyla sonuçlanmıştır. Bu çerçevede Karmatî lideri Ebu Tahir el-Cennâbî’nin (ö. 944), 4 Mart 928'de Rahbe'yi kuşatıp halkın kat1 direncine rağmen ele geçirdiği ve şehirdekilerin bir kısmını öldürdüğü kaynaklarda belirtilir. $^{21}$

Abbasîler tarafindan yeniden elde edilinceye kadar şehir, 10. yüzyıldaki yerel mücadelelerden oldukça zarar görmüştür. 939 yılında Balba adlı bir asi tarafindan ele geçirilerek yeniden bir isyanın merkezi haline gelmiştir. Ancak çok geçmeden Abbasîlerin Türk kökenli komutanı Beckem, şehre gönderdiği adamları vesilesiyle burada yine Abbasî egemenliğini sağlamayı başarmıştır. ${ }^{22} 959$ y1lına gelindiğinde şehrin Hamdanîlerin Halep kolunun kurucusu Seyfüddevle'nin (944-967) kontrolüne geçtiği anlaşılmaktadır. ${ }^{23}$ Aynı devletin Musul kolu hükümdarı olan Nasırüddevle (929-967) zamanında Tağlibîlerden Caman adlı biri şehirde bir isyan hareketini başlatmıştır. Nası̈üddevle, h. 358 (968-969) tarihinde oğlu Hamdan’ı Rahbe şehrine tayin edip şehrin gelirlerini ona tahsis etmiştir. Nasıüddevle'nin ölümü sonrasında (969) oğulları arasında başlayan mücadelede Rahbe yine

17 Bianquis, s. 27; Rousset, s. 258.

18 Kaynakların verdiği kronolojiye göre bu şahıs h. 260 (873-874) y1lında ölmüştür. Bkz. İbnü’l Esir, VI, s. 249. (Türkçe terc. VII, s. 228); İbn Kesîr, el-Bidaye ve’n Nihaye, (Büyük İslam Tarihi), (Çev. M. Keskin), c. XI, İstanbul 1995, s. 73; Zehebî, I, s. 232.

19 Tabarî, XXXVII, (İng terc. P. M. Fields, New York 1987), s. 90, 98; İbnül Esir, VI, s. 330 (Türkçe terc. VII, s. 335); Honigmann, "Rahbe”, $\dot{L}$ A, IX, s. 603; Bianquis, s. 28.

20 Tabarî, XXXVIII, (İng. terc. F. Rosenthal, New York 1985), s. 147; İbnü’l Esir, VI, s. 422 (Türkçe terc. VII, s. 443-444); Aksaraylı Kerimeddin Mahmud, Müsamerat al-Abyar (Selçkî̀ Devletleri Tarihi), (Çev. M. N. Gençosman), Ankara 1943, s. 86.

21 Tabarî, XXXVIII, s. 160; İbn Miskeveyh, Tecaribu'l Ümem, (Çev. K. Burslan), c. I, Ankara 2016, s. 172; İbnü'l Esir, c. VII, s. 38 (Türkçe terc. VIII, s. 152); İbn Kesîr, XI, s. 277; Musil, s. 341; Bianquis, s. 29.

22 Miskeveyh, I, s. 392-393; İbnü’l Esir, c. VII, s. 144 (Türkçe terc. VIII, s. 302); Musil, s. 341.

23 Miskeveyh, II, s. 568. 
paylaşılamayan şehirlerden biri haline gelmiş ve nihayetinde Ebu Tağlib adlı oğlu buray1 ele geçirmiştir. Bunun üzerine Hamdan, önce Dimaşk'a gitmeye karar vermiş ise de sonra ani bir kararla Rahbe’ye dönmüş, kendisine taraftar askerlerin yardımıyla düşman birliklerinin gafletinden istifade ile şehre yeniden hâkim olmuştur. ${ }^{24}$ Ancak onun bu egemenliğinin de uzun süreli olmadı̆̆ı anlaşılmaktadır. Nitekim müellif Miskeveyh'in (ö. 1030) kayıtlarına göre 979 yllında şehir Büveyhî hükümdarlarından Adadüddevle'nin (978-983) elinde bulunuyordu. ${ }^{25}$ Böylece 10. asrın sonlarına doğru Büveyhîlerin kontrolüne geçen Rahbe’ye h. 381 (991-992) y1lında şehir halkının talebi üzerine Büveyhî hükümdarı Bahaüddevle'nin (9891012) emriyle bir vali atanmıştır. ${ }^{26}$

11. yüzyılı yine bir asinin kale şehri olarak karşılamak zorunda kalan Rahbe, bir müddet Ebu Ali el-Hafecî adlı bir isyancının yönetiminde kalmıştır. Ancak bu şahsın şehirdeki hâkimiyeti uzun sürmemiş, İbnü’l Esir'in (ö. 1233) yazdığına göre Misır Fatımî halifeliğinin gönderdiği ordular Rahbe de dahil tüm Suriye'de hâkimiyeti tesis etmiştir. ${ }^{27}$ Anlaşıldığı kadarıyla Rahbe, Suriye ve Irak arasındaki konumu sebebiyle bu asırdan itibaren Abbasî-Fatımî eksenli Sünnî-Şî̀ rekabetini yakından yaşamış, bu dönemde sık sık el değiştirmesi sebebiyle hutbeler bazen Abbasî, bazen de Fatımîler adına okutulmuştur. İbn Kesir (ö. 1373), Rahbe'de Fatımîler adına okutulan hutbenin h. 399 (1008-1009) yilinda Abbasîler adına çevrildiğini yazmaktadır. ${ }^{28} \mathrm{Bu}$ dönemde şehrin bazı yerel emir veya emirliklerin kontrolüne girdiği de görülmektedir. Bu çerçevede Fatımî halifesi Hâkim bi Emrillah (996-1021) zamanında Dımaşk emiri Lü’lu el-Beşşarî tarafından ele geçirilen şehir, aynı yıl Salih b. Mirdas'ın hâkimiyetine girmiştir. Bu sırada şehirde muhtemelen Fatımî hutbesi okunuyordu ki İbnü’l Esir, Salih'in şehri elde ettikten sonra Fatımîler adına hutbe okutmaya devam ettiğini yazmaktadır. ${ }^{29} \mathrm{Bu}$ dönemden itibaren Mirdasî adı şehirle özdeşleşmeye başlamış, Rahbe bölgesi genişleyerek çevresini (Firat Vadisi, Orta Suriye ve Halep) dahi kontrol eder hale gelmiştir. Ayrıca Salih b. Mirdas'ın, Bizans ile yapılan barış anlaşmasının kazandırdığı zaman ve diğer avantajlar sayesinde Rahbe'de birtakım yeni düzenlemelere gittiği söylenir. ${ }^{30}$

Rahbe şehri, 11. yüzyıl ortalarında Selçukluların Horasan'dan batı bölgelerine yönelmeleri ve Irak'1 kontrol altına almaları üzerine siyaseten daha yoğun bir merkez haline gelmiştir. Selçukluların bölgeye geldikleri dönemde Suriye coğrafyası

24 Miskeveyh, II, s. 597, 642, 675; İbnü’l Esir, c. VII, s. 225 (Türkçe terc. VIII, s. 407-408); Musil, s. 341; Honigmann, "Rahbe", $\dot{L}$ A, IX, s. 603.

25 Miskeveyh, II, s. 773. Ayrıca bkz. İbnü’l Esir, c. VII, s. 381(Türkçe terc. VIII, s. 601); Musil, s. 342.

26 İbnü'l Esir, c. VII, s. 457 (Türkçe terc. IX, s. 78-79).

27 İbnü'l Esir, c. VIII, s. 53-54 (Türkçe terc. IX, s. 171-172); Honigmann, "Rahbe”, 亡A, IX, s. 603.

28 İbn Kesîr, XII, s. 133.

29 İbnül Esir, c. VIII, s. 53 (Türkçe terc. IX, s. 171).

30 Rousset, s. 245. 
bütünüyle Fatımî egemenliği altında bulunuyor, Rahbe ise bu coğrafyada Misır halifeliğinin doğu sınırındaki ileri karakollardan biri olarak görev yapiyordu. Tuğrul Bey’in, h. 447 (1055-1056) y1lında Bağdat'a gelmesi ve kısa sürede tüm Irak'a egemen olmasıyla buradaki Fatımî varlı̆̆ı Suriye sınırları içerisine çekilmek zorunda kalmıştı. Bu sırada Fatımî yönetimi adına Bağdat'ta görev yapan Arslan Besasirî de süratle Suriye'deki en güvenli kalelerden biri olan Rahbe’ye iltica etmiş, burada Fatımî halifesi Müstansır-Billah (1038-1094) ile irtibata geçerek asker ve para yardımı gelmesini beklemişti. ${ }^{31}$ Fatımî halifesi, Besasirî’yi şehrin emirliğine atayarak talep ettiği yardımları göndermeye söz vermişti. ${ }^{32} 1060$ yılında Besasirî, Tuğrul Bey'in adamları eliyle öldürüldüğünde Rahbe halen onun hâkimiyetinde bulunuyor, şehirdeki hutbeler de Fatımî halifesi adına okutuluyordu. ${ }^{33}$ Kaynaklarda yer alan bilgiye göre Besasirî'nin ölümünden sonra Esedüddin Ebu Suabe Atiyye b. Salih elKilabî, Rahbe'ye giderek onun bıraktığı çok sayıda silah ve malların hepsini ele geçirmişti. 1065 yilına gelindiğinde şehir halen bu şahsin elinde bulunuyordu. ${ }^{34}$

Rahbe, erken dönem Selçuklu hükümdarlarının gelecek planlarında yer eden bir şehir olmuştur. İlk Selçuklu hükümdarı Tuğrul Bey, Irak’a geldiği sırada Fatımîlerin elinde bulunan şehrin öneminin farkında olduğundan hanedan üyelerini bölgeyi ele geçirmeye teşvik etmiş, 1057 yılında kendisine bir arazi tahsis edilmesini talep eden üvey kardeşi İbrahim Yınal'a Rahbe’yi işaret ederek: "Biz ancak sana senin fethettiğin yerleri veririz; eğer Rahbe'ye gidersen orası senin olsun” demiştir. ${ }^{35}$ Sonraki dönemlerde Selçuklu sınırlarına dâhil edildiğinde Selçuklu hükümdarları Rahbe yönetimini genellikle yerel hükümdarlara havale etmişlerdir. Bu çerçevede h. 460 (1067-1068) yılında Ukayloğullarından Şerefüddevle Müslim b. Kureyş’in Rahbe’ye hâkim olduğu görülmektedir. Müslim, bölgede Fatımîlere bağl1lığını sürdürerek yağma faaliyetlerinde bulunan Kilaboğulları kabilesini Rahbe önünde mağlup etmiş, böylece Rahbe yeniden Abbasîlere bağlanarak şehirdeki Fatımî-Şiî yönetimi son bulmuştur. ${ }^{36}$ Sultan Melikşah'ın, h. 479 (1086-1087) yılında

31 Bkz. Azimî, Az̧imî Tarihi (Selcuklular Dönemiyle İlgili Bölümler H.430-538=1038/39-1143/44), (Çev. A. Sevim), Ankara 2006, s. 16; İbnü'l Adim, Zübdetü'l-Haleb Min Tarihi Haleb'de Selcuklular, c. I, (Seçme, Tercüme ve Değerlendirme: A. Sevim), Ankara 2014, s. 8; İbnü’l Esir, c. VIII, s. 325 (Türkçe terc. IX, s. 465), İbn Kesîr, XII, s. 167; Ahmed b. Mahmud, Selcuk-nâme, (Haz. Erdoğan Merçil), c. I, İstanbul 1977, s. 38.

32 Abdurrahman İbnü’l Cevzî, el-Muntazam fi Taribi'l Ümem'de Selçuklular, (Seçme, Tercüme ve Değerlendirme: A. Sevim), Ankara 2014, s. 18; İbnü'l-Kalanisî, Taribu Dımaşk (360-555), (Neşr. Süheyl Zekkar), Dımaşk 1983, s. 145. (Türkçe terc. Hasan Aydın, İbn Kalanisi, Hayatı ve Eserleri, "Zeylü Tarih-i Dımaşk" Tercümesi (s. 142-549), Marmara Üniversitesi Türkiyat Araştırmaları Enstitüsü, (Yayımlanmamış Yüksek Lisans Tezi), İstanbul 2016 s. 10).

33 Sıbt İbnül Cevzî, Mir'âtü'z-Zaman fi Taribi'l Ayan (Selçuklular Kısmı), (Seçme, Tercüme ve Değerlendirme: Ali Sevim), Ankara 2011, s. 18; Zehebî, I, s. 384.

34 İbnü’l Adim, I, s. 8-10; İbn Kalanisî, s. 151 (Türkçe terc. s. 15); İbnü’l Esir, c. VIII, s. 353 (Türkçe terc. X, s. 31); İbn Kesîr, XII, s. 195; Zehebî, I, s. 389; Musil, s. 342.

35 Sibt İbnü'l Cevzî, s. 40.

36 Bianquis, s. 37; Musil, s. 342; Gülay Öğün Bezer, "Müslim b. Kureyş”, D亡், c. 32, İstanbul 2006, s. 95 . 
Rahbe ile birlikte Harran, Suruç, Rakka ve Habur gibi yerleşimleri Şerefüddevle'nin oğlu Muhammed'e ikta etmesiyle şehirdeki Ukayloğulları idaresinin bir müddet daha devam ettiği görülmektedir. ${ }^{37} 1090$ yılında tüm Diyar-1 Rebia ile birlikte Rahbe kalesinin de Fahrüddevle Cüheyr'in (ö. 1091) yönetimine terk edildiği bilinmektedir. ${ }^{38}$ Fahrüddevle'nin ölümünden sonra bir müddet Melikşah'ın bölge valilerinden Kasımüddevle Aksungur elinde kalmıştır. ${ }^{39}$

Melikşah'ın ölümü (1092) sonrasındaki politik gelişmeler, tüm Selçuklu coğrafyasında olduğu gibi Suriye’de de merkezi yönetimi derinden sarsmıştır. Suriye hem merkeze çok uzak olması hem de Misır halifeliğinin öteden beri kolladı̆̆ bir coğrafya olması sebebiyle bu parçalanmışlı̆̆1 daha fazla hissetmiştir. Bu siyasi belirsizlik ve istikrarsızlık ortamı, Suriye'deki şehirlerin tabi bu arada Rahbe'nin yerel hanedan ve beyler arasında sürekli el değiştirmesine sebep olmuştur. Nitekim Melikşah'ın ölümüyle saltanat iddiasıyla harekete geçen kardeşi Tacüddevle Tutuş, 1092'de Suriye'de hâkimiyetini tescil ettikten sonra h. 486 (1093-1094) yilinda Aksungur, Yağısıyan ve Bozan gibi meşhur bölge emirlerini de yanına alarak hızlı bir şekilde Rahbe'ye ulaşıp buradaki egemenliğini kolayca tesis etmiştir. ${ }^{40}$ İbn Kalanisî (ö. 1160), şehrin Tutuş tarafindan kuşatılma süreciyle ilgili detaylar sunmaktadır. Buna göre, Tutuş ilk seferinde şehri kendilerine teslim etmesi için halka mektup yazmış, fakat bu talebi reddedilmişti. Bunun üzerine şehirden ayrılmak zorunda kalan Tutuş, Aksungur ve Yağısıyan'ın desteğini alarak daha güçlü bir şekilde Rahbe önlerine gelmiş ve bu kez hiç zorlanmadan şehri ele geçirmiştir. Müellifin yazdı̆̆ına göre, kılıçla elde etmesine rağmen halka iyi davranmıştı, ancak "savaş yoluyla veya emanla şehri ele geçirirsem mutlaka şehirde kılıcımı kınından çıkaracağım” şeklinde kendi kendine söz verdiği için şehre girdiğinde kılıcını kınından çıkarmış ve işler yoluna girinceye kadar da kınına sokmamışt1, böylece yeminini yerine getirmiş oluyordu. ${ }^{41}$ Rahbe'ye bu şekilde hâkim olan Tutuş burada sultanlı̆̆ını ilan etmiş, ancak bu sırada en güçlü rakibi Berkyaruk'un kendisiyle karşılaşmak için Rahbe’ye doğru geldiğini duyunca buradan süratle ayrilıp Antakya taraflarına çekilmiştir. ${ }^{42}$ Halepli tarihçi İbnü'l Adim (ö. 1262), Tutuş’un Berkyaruk ile mücadele halinde bulunduğu 1094 yllında Rahbe'nin Abakoğlu Yusuf adlı birinin elinde olduğuna dair bir kayıt düşmektedir. Bu bilgiyi teyit eden İbn Kalanisî’nin kayıtlarından yola çıkarak bu kişinin Tutuş’un bu

37 İbnü’l Esir, c. VIII, s. 450 (Türkçe terc. X, s. 143); İbnü’l Verdî, Bir Ortacă̆ Sairinin Kaleminde Selçuklular, (Tercüme ve Notlar: M. Alican), İstanbul 2017, s. 43; el-Ömerî, Türkler Hakkanda Gördüklerim ve Duyduklarm (Mesalikï̈l Ebsar), (Çev. A. Batur), İstanbul 2014, s. 224; İbn Kesîr, XII, s. 264; Zehebî, I, s. 412; Ashtor, s. 178-179; Honigmann, "Rahbe", IA, IX, s. 603.

38 İbnü’l Ezrak, Tarih-i Meyyafarikin, (Mervani Kürtleri Taribi), (Çev. M. E. Bozarslan), c. I, İstanbul 1990, s. 203.

39 Bkz. Ziya Polat, Umut Iradesi: İmâdüddin Zengî, İstanbul 2019, s. 25.

40 Azimî, s. 33; İbnü’l Esir, c. VIII, s. 487 (Türkçe terc. X, s. 189); İbn Kesîr, XII, s. 286; Polat, s. 26.

41 İbn Kalanisî, s. 200-201 (Türkçe terc. s. 43).

42 İbn Kalanisî, s. 204 (Türkçe terc. s. 46). 
bölgedeki varlığına karşı olduğunu söyleyebiliriz. Nitekim adı geçen müellifin yazdığına göre aynı yıl Abakoğlu Yusuf, Tutuş’a karşı Bozan ve Aksungur ittifakına 2.500 kişilik bir süvari birlikle yardıma gelmiştir. ${ }^{43}$

Tutuş’un 1095'teki Berkyaruk'a karşı saltanat mücadelesi için giriştiği savaştaki ölümü, hâkim olduğu Suriye şehirlerinde yeni bir istikrarsız dönemin fitilini ateşlemiştir. 1096 yllına gelindiğinde Rahbe'yi dönemin muhteris Selçuklu komutanlarından Kürboğa'nın elinde görüyoruz. Bu yıl şehir önlerinde görünen Kürboğa, şehre girilmesine izin verilmeyince şehri kıllçla ele geçirmiş ve yağmalamıştır. ${ }^{44}$ Tam bu döneme tesadüf eden Haçlı saldırıları, özellikle Suriye'de siyasi-coğrafi parçalanmışlı̆̆ın ve yerel hükümetler arasındaki bloklaşmanın artmasına sebep olmuştur. Kaynaklarda belirtildiğine göre, Kürboğa'nın ölümünden sonra şehir 1102 y1lında kısa süreli olarak Alp Arslan'in komutanlarından Kaymaz'ın eline geçmiş, Kaymaz'ın ölümü sonrası onun damadı Emir Hasan adlı biri şehre hâkim olmuştu. Bu kişinin şehir halkına oldukça kötü davrandığı, askerleri ve ileri gelenleri hapse attırarak geri kalanları da ağır vergilere bağladığ1 söylenir. Bu olaylar üzerine şehri ele geçirmeye azmeden Tutuş’un oğlu Dukak, 1103 yılinda çetin bir kuşatmadan sonra bu amacina ulaşmış, şehre bir birlik yerleştirdikten sonra aynı yılın Nisan ayında Rahbe'den ayrılmıştır. ${ }^{45}$ Dukak'ın 1104 y1lındaki ölümü sonrası kaynaklarda adı Bektaş olarak kaydedilen kardeşinin geçici süre Rahbe'ye egemen olduğu belirtilir. ${ }^{46}$ Ancak Dukak'ın öldügünü duyan muhteris bölge valileri soluğu şehrin önünde almış, bunlardan Musul valisi Çavlı, hemen şehre gelerek 70 gün sürecek olan şiddetli bir kuşatmaya koyulmuştur. Şehri ele geçirmek için Artukoğlu İlgazi'den askeri yardım alan Çavlı, tam bu sırada Fırat'ın suları taşmasıyla halktan bazı kişilerle anlaşıp askerlerini kayıklarla şehre sokmayı denemişti. Neticede surları aşan askerler şehri ele geçirmiş ve hemen şehri yağmaya koyulmuşlardı. Bu sırada askerlerin yağması karşısında Rahbe halkının zor anlar yaşadıkları kaydedilir. Ancak Çavlı'nın, yağmayı sonlandırmasıyla halk emniyetle evlerine dönebilmişti. Böylece Çavlı, 29 May1s 1107 tarihinde Rahbe'yi Dukak'ın şehirdeki valisi Şeyban oğullarından Muhammed b. es-Sebbak'ın elinden almışt1. ${ }^{47}$

Rahbe şehrinin Haçlıların bölgeye gelmeleri sonrasında İslam ülkelerinin güvenliği açısından eskisine oranla çok daha fazla bir önem kazandığ1 söylenebilir. $\mathrm{Bu}$ süreçte şehir, Irak ve Suriye topraklarını birbirinden ayıran korunaklı yapısıyla

43 İbnü'l Adim, II, s. 70; İbn Kalanisî, 207 (Türkçe terc. s. 48).

44 İbnü'l Esir, c. IX, s. 5 (Türkçe terc. X, s. 217).

45 İbn Kalanisî, s. 229 (Türkçe terc. s. 67); İbnü’l Adim, II, s. 101; İbnü’l Verdî, s. 59; İbnü’l Esir, c. IX, s. 67 (Türkçe terc. X, s. 295); İbn Kesîr, XII, s. 315; Musil, s. 343; Bianquis, s. 38-39.

46 İbnü’l Esir, c. IX, s. 74 (Türkçe terc. X, s. 305).

47 Azimî, s. 40-42; İbnü'l Esir, c. IX, s. 106 (Türkçe terc. X, s. 344); Abu'l Farac, Abu'l Farac Taribi, (Çev. Ö. R. Doğrul), c. II, Ankara 1999, s. 348. Kalanisî, şehir valisinin kuşatma sırasında Çavlı’ya karşı Kılıç Arslan'dan yardım talep ettiğini, Kılıç Arslan'ın da bu amaçla yola çıktığını ancak şehrin düştüğünü öğrendiğinde geri döndüğünü de yazmaktadır. Bkz. İbn Kalanisî, s. 251-252 (Türkçe terc. s. 85-86). 
hem Haçlılar üzerine gerçekleştirilen seferler hem de onlardan gelecek saldırıları bertaraf etmede vazgeçilmez bir üs görevi üstlenmiştir. İbnü’l Esir'in kronolojisine göre 1108 yılında Rahbe Selçuklu sultanı Muhammed Tapar tarafindan Ispehbad Sebave adlı bir komutana ikta edilmişti. ${ }^{48}$ Ancak bunun çok uzun sürmediği anlaşılıyor, çünkü kaynaklar Haçlılarla mücadele etmesi için Musul emirliğine atanan Aksungur el-Porsikî’nin 1108-1109 yllında şehre hâkim olduğunu yazarlar. ${ }^{49}$ Bu dönemde Rahbe, Musul komutanlarının bölgede gerçekleştirecekleri seferler için kritik bir üs olarak görüldüğü gibi onların olağanüstü durumlarda sığınacakları korunaklı bir kale görevini üstlenmişti. Nitekim Aksungur el-Porsikî, Sultan Muhammed Tapar tarafindan görevden azledildiğinde güvenliği için Rahbe şehrine çekilmişti. ${ }^{50}$ Sonraki dönemlerde Haçlılara karşı mücadele için Musul'a atanan Mevdud, Çökürmüş ve Zengi gibi komutanlar için Rahbe şehri coğrafi pozisyonu itibariyle önemini korumuştur. Özellikle bölgeyi tek çatı altında birleştirme idealine sahip olan İmadüddin Zengi, şehrin bu stratejik konumunun ziyadesiyle farkındaydı. Bu dönemde şehrin bölge valileri arasında anlaşmazlık konusu olduğu, bu vesileyle sık sık el değiştirdiği anlaşılmaktadır. ${ }^{51}$ Neticede Haçlilara karşı mücadeleye girişmeden önce bu korunaklı kaleyi ele geçirmeyi önemseyen Zengi komutanlarından birini göndererek 1126 'da şehri ele geçirdi. ${ }^{52}$

İmadüddin Zengi'nin ölümünden sonra (1146) oğlu Kutbeddin'in 11491150 'de bir müddet şehre hâkim olduğu anlaşılmaktadır. Ancak Zengi'nin diğer oğlu Nureddin, aynı yıl kardeşiyle mücadeleye girişerek Rahbe'yi Kutbeddin'in elinden almıştır. ${ }^{53} \mathrm{Bu}$ sırada Şam ve Halep şehirlerini ele geçirerek Suriye'deki durumunu güçlendiren Nureddin, 1164 yllinda şehrin yönetimini sadık hizmetkarlarından Şirkuh'a (Selahaddin'in amcası) bırakmış ${ }^{54}$ o da buranın idaresini bir zabit olan Yusuf b. Mallah'a devretmişti. Daha sonraki dönemlerde Rahbe'nin, Humus ile birlikte bir müddet Şirkuh'un oğlu Nasırdüddin'in yönetimine havale edildiği görülmektedir. ${ }^{55}$ Bir ara Eyyubî hükümdarı el-Melik Kâmil'in oğlu (1238 yılında) Melik Salih, emrindeki Harizm askerleriyle birlikte Rahbe'yi kuşatmış ise de

48 İbnüll Esir, c. IX, s. 122, 127 (Türkçe terc. X, s. 364, 370).

49 Azimî, s. 44.

50 İbnü'l Verdî, s. 73; İbnü’l Adim, II, s. 129; el-Ömerî, s. 247. Kılıç Arslan karşısında duramayan Çavlı, bu şehre sığınarak zaman kazanmıştı. Çavlı aynı şekilde Mevdud'a karşı verdiği mücadele sırasında şehri önemli bir sığınak noktası olarak kullanmıştır. İbn Kalanisî, s. 251-252, 256 (Türkçe terc. s. 85-86, 89); İbn Kesîr, XII, s. 323.

51 İbn Kalanisî, s. 251-252 (Türkçe terc. s. 72, 85, 138); el-Ömerî, s. 252-253.

52 Süryani Mihail, Vekayinâme, (Çev. H. D. Andreasyan), (Basılmamış TTK Nüshası), 1944, s. 52; İbnü’l Esir, c. IX, s. 242-243 (Türkçe terc. X, s. 509-510); Abu'l Farac, II, s. 360; İbnü’l Verdî, s. 82; Polat, s. 72.

53 Krş. İbnü’l Esir, c. IX, s. 360-361 (Türkçe terc. XI, s. 128); İbn Kesîr, XII, s. 414.

54 Süryani Mihail, s. 197; Abu'l Farac, II, s. 401; İbn Kesîr, XII, s. 467; Herzfeld, II, s. 383.

55 İbnü’l Esir, c. X, s. 135 (Türkçe terc. XI, s. 409); Yakut el- Hamevî, III, s. 34-35; İbn Kesîr, XIII, s. 18,75 . 
babasının ölüm haberi üzerine kuşatmayı kaldırmak zorunda kalmıştır. ${ }^{56}$ Böylece Şirkuh ailesi, Sultan Baypars'ın 1264 yılında şehri ele geçirip bir Misır valisi yerleştirdiği güne kadar tam bir asır boyunca Rahbe'yi elinde tutmayı başarmıştı. ${ }^{57}$

Rahbe, 13. asrın başlarından itibaren İslam dünyasını kuşatan Moğol istilasına karşı sağlam bir kale şehir olarak görev yapmaya devam etmiştir. Bu dönemde Moğolların hâkimiyetinde bulunan Irak ile Memlük sınırları içinde yer alan Suriye'yi birbirinden ayıran şehir, bu konumuyla doğal olarak iki düşman devletin savaş sahası haline gelmiş, özellikle Moğolların Suriye üzerine gerçekleştirdikleri sefer güzergahının ilk ve en önemli duraklarından biri olmuştur. Zaten bu dönem metinlerinde şehir daha çok güçlü kalesi ve Moğol istilalarına karş1 savunma rolü vesilesiyle gündeme gelir. ${ }^{58}$ Tarih-i Baypars'ta bahsedildiğine göre Memlük sultanı Baypars, 1273 yılında Tatarlardan bir firkanın Rahbe'ye geldiklerini haber aldığında süratle şehir üzerine yürümüş, Suriye'deki diğer birçok kritik kale ile birlikte Rahbe'yi de geri almıştır. ${ }^{59}$ Rahbe'nin Moğollar ile Memlükler arasında sınır kalelerinden biri olmas1, iki taraftan birine isyan eden komutan ve askerlerin buraya sığınıp karşı tarafla irtibata geçmesine de vesile olmuştur. Mesela 1280 yılında Memlük sultanı Kalavun’dan (1279-1290) kaçan Sunguru’l Eşkar adlı Memlük emiri Rahbe’ye sığınarak Moğol hükümdarı Abaka (1265-1282) ile irtibata geçmiş ve onu Şam’a davet etmişti. Ancak Moğollar bölgeye geldiklerinde onların kendilerini öldürmesinden korkarak Sabyun Kalesi'ne* kapanmıştı. ${ }^{60}$ Aynı şekilde Memlük tarihçisi İbn Tağriberdî (ö. 1470), sultan Ketboğa (1294-1296) döneminde İlhanlı hükümdarı Gazan Han'dan (1295-1304) kaçarak Rahbe’ye gelen yaklaşık 10 bin çadırlık Tatar askeri gücünün Memlüklere iltica ettiklerini ve burada Müslüman oldukların1 yazar. ${ }^{61}$

Gazan Han döneminde gözle görülür şekilde artan Suriye seferleri sırasinda Rahbe, Moğollar tarafından sıkça kuşatılmış ve şiddetli saldırılara maruz kalmıştır. 1300 y1lında Diyarbekir ve Resülayn üzerinden gelerek Rahbe'de karargâh kuran Moğol askerleri, Memlüklerin kısa süre içinde bölgeye ulaşmasıyla Halep civarında onlarla sabahtan akşama kadar süren bir çarpışmaya tutuşmuşlar, neticede Memlükler mağlup olarak çekilmek zorunda kalmışlardı. ${ }^{62}$ İbn Tağrıberdi'nin

56 İbn Vâsıl, Müferricül-Kurub fi Abbari Beni Eyyub, c. V, (H. M. Rebi-S. Abdulfettah Asur), Kahire, ts. s. 178.

57 Musil, s. 344; Honigmann, "Rahbe", $\dot{L}$ A, IX, s. 603.

58 Ebü’l Ferec İbnü'l İbrî, Taribu Mubtasari'd-Düvel, (Çev. Ş. Yaltkaya), Ankara 2011, s. 57; Rousset, s. 258.

59 Anonim, Baypars Taribi, (Çev. Ş. Yaltkaya), Ankara 2000, s. 17-18; İbn Kesîr, XIII, s. 469; İbn Tağriberdî, en-Nücumu'z Zahire, (Parlayan Yıldı̨lar), (Çev. A. Batur), İstanbul 2013, s. 51.

* Lazkiye'den 1 merhale mesafeye yerleşen bir kale olup kaya üzerinde inşa edilmiş sağlam bir yapıdır. Ahalisi İsmaililiğe mensuptur. Kâtip Çelebi, s. 673.

60 İbnü’l İbrî, Mubtasar, s. 51; Zehebî, II, s. 201-203.

61 İbn Tağriberdî, s. 85.

62 Aksaraylı Mahmud, s. 313-314; İbn Tağrıberdî, s. 97. 
kayıtlarına göre, iki yıl sonra 1302 y1lında Gazan Han 80 bin kişilik bir orduyla Suriye seferine çıkma kararı almış ve bu vesileyle bir kez daha Rahbe önlerinde görünmüştü. Sonraki Moğol hükümdarı Olcaytu (1304-1316) döneminde de Moğollar ile Memlükler arasındaki rekabet ve düşmanlığın ana merkezlerinden biri olan Rahbe, Moğol ordularının Suriye'ye yaptıkları seferlerin ilk ve en önemli durağını oluşturacaktı. ${ }^{63}$ Bu çerçevede h. 712 (1312-1313) senesinde Moğol orduları tarafından kuşatılmış ancak ele geçirilememiştir. Söylendiğine göre bu geri çekilme sırasında Moğol ordusunun biraktığı muhasara aletleri sonradan Rahbe kalesine taşınmıştır. ${ }^{64}$ Neticede Moğolların Suriye'yi ele geçirmek iddiasıyla Rahbe üzerinden başlattıkları bütün bu seferler uzun vadede başarısız olmuş, Rahbe şehri savunmaya elverişli konumuyla Moğolların Suriye topraklarına girmelerinin engellenmesi noktasında Memlük Devleti'ne dikkate değer bir hizmet sunmuştu.

Rahbe Kalesi, bu şekilde Moğol saldırılarına karşı çok kritik bir görev üstlendikten sonra bölgede kalan son Moğol grupların da çekilmesi sonrası önemini yitirmeye başlamıştır. Kalenin bakımı oldukça maliyetli olduğundan ve Moğol tehdidi kalmadığından kale Memlük güçleri tarafindan kademeli olarak boşaltılmıştır. ${ }^{65}$ Söylendiğine göre Rahbe, böylece büyük ölçüde terk edilmiş olduğundan Humus hâkimi Şirkuh İbn Muhammed tarafindan h. 721 (1321-1322) y1lında Firat'tan takriben bir fersah ötede bir hisar ile Rahbetü'l Cedid (Yeni Rahbe) inşa edilmiştir. ${ }^{66}$ Rahbe mintıkası bu tarihten sonra yerel hanedanlıkların bölgedeki birtakım siyasi mücadeleleri vesilesiyle nadiren gündeme gelmiştir. Şehir, 15. yüzyıl başlarında Anadolu, Irak ve Suriye'de hızlı bir şekilde güçlenen Timur ile mücadele halinde olan Karakoyunlu hükümdar1 Kara Yusufun (1389-1420) bölgedeki faaliyetleri çerçevesinde seyrek olarak anılır. ${ }^{67}$ Orta Çağ1 kapatan hadiseler, Rahbe'nin görkemli geçmişine muhalif sessizlik dönemine girmesinin de başlang1c1 olmuş, Osmanlı egemenliğinin başlamasıyla hızlı şekilde önemsizleşen şehir birkaç harabesiyle günümüze intikal edebilmiştir. 17. asırda bölgeden geçen P. Della Valle (ö. 1652) ve J. B. Tavernier (ö. 1689) gibi seyyahlar buranın Orta Çağdan kalma harabeleri içinde barından küçük bir yerleşim olduğunu söyleyip geçiştirirler. ${ }^{68}$ Tavernier'in, kalıntıların hayvancılıkla uğraşan kişilere barınak olduğu yönündeki kayıtları şehrin bu dönemde siyasi-askeri tüm önemini yitirdiğini ve tamamen kaderine terk edildiğini göstermesi bakımından dikkate değerdir. ${ }^{69}$ Yüzeydeki kalın

63 İbn Tağriberdî, s. 109, 137; Hamdullah Müstevfî-yi Kazvinî, Tarih-i Gü̊ide, (Çev. M. Öztürk), Ankara 2018, s. 494.

64 Musil, s. 344; Honigmann, "Rahbe", $\dot{L} A$, IX, s. 603.

65 Rousset, s. 259.

66 Bkz. Ebü'l Fida, s. 237; Kâtip Çelebi, s. 533; Musil, s. 344. Honigmann, bugünkü Meyadin şehrinin güneybatısında bulunan harabe halindeki hisarın bu Yeni Rahbe'ye ait olduğunu belirtmektedir. Honigmann, "Rahbe", $\dot{I}$ A, IX, s. 603.

67 İbn Tağriberdî, s. 364.

68 Honigmann, "Rahbe", $\dot{I} A$, IX, s. 604.

69 Jean-Baptiste Tavernier, Tavernier Seyehatnâmesi, (Çev. T. Tunçdoğan), İstanbul 2006, s. 301. 
gübre katmanları, bu dönemde sakinlerinin çoğunlukla çoban olduğu tezini doğrulamaktadır. ${ }^{70}$

\section{Sosyo-ekonomik Anekdotlar}

Her şehrin olduğu gibi Rahbe'nin de siyaset dışı bir tarihi vardır ve seyyahların gözlemleri bu noktada değer arz etmektedir. Seyyahlara göre Rahbe, korunaklı kalesi dışında suyu bol, tarım arazisine sahip bir yerleşimdir. Rahbe'de tarımsal çeşitliliği tetikleyen en önemli etken kuşkusuz şehrin bu su imkanlarına sahip olmasıdır. Şehrin, pozisyonu itibariyle hem Firat Nehri hem de kaynaklarda Said Nehri adı verilen bir nehir tarafindan kuşatılmış olması su imkanlarının fazla olmasını sağlamıştır. ${ }^{71}$ 10. asırda Abbasî maliyesi ile alakalı önemli bir eser kaleme almış olan Kudâme İbn Cafer (ö. 948 [?]) bu zenginliğe işaret eden şu kayıtları düşer: "Rabbe suyu eskiden kapatılmıstı. Kirman hacılarından biri bunun sızdı̆̆m gördü. Hacdan dönerken Isa b. Musa'ya geldi. Ona bu suyu gösterdi. Musa bu suyun ve arazisinin kendisine ikta verilmesini istedi. Kirmanl onun için suyu çıkardı. Etrafindaki araziyi işledi. Uzeyb yolu üzerindeki hurmalĭg meydana getirdi."’72

Sulama imkanlarının bol olduğu bir arazinin üst düzey bir tarımsal çeşitliliğe sahip olması tabiidir. Nitekim seyyahlar, Rahbe'deki meyve ağaçlarının bolluğu ve verimliliğinden övgüyle bahsederler. 10. yüzyıl seyyahı İbn Havkal'ın gözlemlerine göre şehrin hurması ve meyvesi meşhurdur ve bol su ile sulanan bir tarımı vardır. ${ }^{73}$ Özellikle bölgedeki en kaliteli ayvanın merkezi bu dönemde Rahbe'dir. Hamdullah Müstevfî de şehrin meyvelerini överek elma, ayva, armut ve üzümünün iyi kalitede olduğundan söz eder. O ayrıca şehirdeki ağaçların yılda iki kez meyve verdiğine dair söylentiyi de aktarır. ${ }^{74}$ Şehrin vergi gelirleriyle ilgili ilk ve en değerli bilgiyi Kudâme İbn Cafer vermektedir. Onun belirttiğine göre Rahbe şehri Hit, Ane ve Kurkisya şehirleriyle birlikte Fırat yolu âmillikleri içerisinde bulunmaktadır ve bu şehirlerin toplam vergi gelirleri y1llık 2 milyon 900 bin dirheme tekabül etmektedir. ${ }^{75}$

Rahbe, Irak ve Suriye toprakları arasında yerleşen müstahkem konumuyla Orta Çağ boyunca sadece siyasi açıdan değil ticari yönden de önem arz eden bir şehir olmayı başarmıştır. Kurulduğu dönemden itibaren uluslararası ticaretin önemli menzillerinden biri olarak görev yapmaya başlayan şehir, Firat hattı üzerinde Halep ve Bizans topraklarından gelen kervanlar için güvenli bir durak noktası haline gelmiştir. ${ }^{76}$ Muhtemelen bu sebeple İslam coğrafyacıları, ticaret yollarını tanımlarken Rahbe'yi Fırat'ın ağzında önemli bir çıkış noktası olarak betimlemişlerdir. Ebü’l Fida, 12. yüzyıl sonları ve 13. yüzyıl başlarında ticari açıdan

\footnotetext{
70 Rousset, s. 259.

71 Bkz. Ibn Serapion, s. 68; Ebü'l Fida, s. 237. Honigmann, "Rahbe”, IA, IX, s. 603.

72 Kudâme İbn Cafer, s. 74.

73 İbn Havkal, s. 190; Honigmann, "Rahbe", $\dot{L}$ A, IX, s. 603-604.

74 Mustawfi, Nuð̧at-al-Qulub, s. 242-243. Herzfeld, II, s. 382; Le Strange, s. 124.

75 Kudâme İbn Cafer, s. 153. Ayrıca bkz. Ashtor, s. 173.

76 Bianquis, s. 27; Rousset, s. 243.
} 
Şam ve Irak'tan gelen kervanlar için önemli bir menzil olduğunun altını çizmektedir. ${ }^{77}$ 14. yüzyıl başlarında şehrin bir fersah güneyinde kurulan Yeni Rahbe'nin de Suriye ve Irak arasında seyreden kervan ticareti bağlamında aynı öneme haiz olduğu bu asrın seyyahı olan İbn Battuta'nın gözlemleriyle sabitlenmiştir. ${ }^{78}$ Ticari açıdan hareketli bir şehir olması Rahbe'nin bir darphaneye sahip olmasını zorunlu kılmış görünüyor. Şehirde basılmış olup günümüze ulaşan en erken döneme ait paralar Abbasî çağına tarihlenir. Halife el-Muktedir Billah (908-932) döneminde şehirde görsel figürler içermeyen süslü hat ile tezyin edilmiş altın ve gümüş paralar darp edilmiştir. (Bk. Resim VII)

Rahbe, Orta Çağ boyunca savaşlar ve kuşatmalarla gelen afetler dişında salgin hastalık, sel, kitlık, deprem ve yangın gibi doğal afetler ile de yüzleşmek zorunda kalmıştır. İbn Kesir'in belirttiğine göre h. 476 (1083-1084) yılında şehirde meydana gelen veba salgını sebebiyle Rahbe halkından 10 bin kadar kişi ölmüştür. ${ }^{79}$ Aynı şekilde h. 519 (1125-1126) yllında bölgede meydana gelen kıtlık Rahbe'nin de içinde bulunduğu bazı şehirlerde fiyat artşslarına neden olmuş, hatta bu sebeple bazı insanlar açlıktan ölmüşlerdi. ${ }^{80}$ Çok geçmeden kaynaklarda sıkça bahsedilen 12 Ağustos 1157 depremi Şayzer, Hama, Halep ile birlikte Rahbe'yi de önemli ölçüde tahrip etmişti. ${ }^{81}$ Beş yll sonra 1162 yılının Mayıs-Haziran aylarında çıkan yangında ise şehrin hanı ve hububat satan dükkanlarının önemli ölçüde zarar gördüğü belirtilir. ${ }^{82}$ Şehrin Fırat kenarında kurulmuş olması zaman zaman sel felaketleriyle de yüzleşmesine sebep olmuştur. İbn Kesir'in kayıtlarına göre h. 732 (1331-1332) y1lında Firat'ın taşmasıyla meydana gelen ve 12 gün süren sel felaketi şehirde büyük maddi zararlara yol açmıstr..$^{83}$

Bir afet olarak kabul edilebilirse Rahbe ve civarında kaynaklarda sıkça bahsedilen bedevi yağmalarından da bahsetmek gerekir. Çöl mıntıkasına yakın bir coğrafyaya yerleşmesi, şehrin kurulduğu tarihten itibaren bölgede yuvalanmış bedevilerin yağma amaçlı saldırılarıyla yüzleşmesine sebep olmuştur. Bu konuda ilk kaydı düşen Taberî'ye göre bedevi Araplar 904 yılında Rahbe'ye saldırmış ve halkın Ramazan Bayramı'nı eda ettiği sırada birçok insanı öldürmüşlerdi. ${ }^{84}$ Müteakip asırlarda bedevi kabileler ile Bağdat yönetimi arasında meydana gelen şiddetli çarpışmalarda Rahbe halkının da taraf olduğu görülüyor. İbnü’l Esir, h. 556 (11601161) yılı vukuatı içinde Bağdat yönetimi ile Haface kabilesi arasında meydan gelen

\footnotetext{
77 Ebü’l Fida, s. 237; Kâtip Çelebi, s. 533.

78 Honigmann, "Rahbe", $\dot{L} A$, IX, s. 603-604.

79 İbn Kesîr, XII, s. 232.

80 İbn Kalanisî, s. 338 (Türkçe terc. s. 152).

81 İbn Kalanisî, s. 527 (Türkçe terc. s. 287); Süryanî Mihail, s. 182; Abu’l Farac, II, s. 397; Musil, s. 343.

82 İbnü’l Esir, c. IX, s. 459 (Türkçe terc. XI, s. 236).

83 İbn Kesîr, XIV, s. 257; Musil, s. 3, not 3; Honigmann, "Rahbe", 亡A, IX, s. 603.

84 Tabarî, XXXVIII, s. 147; Aksaraylı Kerimüddin Mahmud, s. 86.
} 
bu tür bir hadiseyi aktarır. ${ }^{85}$ Aynı şekilde h. 764 (1362-1363) y1lında Rahbe’ye giden Memlük askerleri bu bölgedeki bedevilerin saldırısına uğramış, askerlerin bir kısmı öldürülerek malları yağmalanmış, bir kısmı da yaralı olarak kurtulmuşlardı. ${ }^{86}$ Görüldüğü gibi bölgede yağmacıllğı bir meslek haline getiren bedeviler için ister asker olsun ister tüccar çöl yolundan geçen herkes kazançlı bir müşteri gibi görülmüştür. İbn Tağrıberdi'nin kayıtlarına göre 1403 yılında Timur'un takibinden kaçarak Rahbe'ye sığınan Karakoyunlu hükümdarı Kara Yusuf ve efradı da böyle bir akıbete maruz kalmışlardı. ${ }^{87}$ Kara Yusufun ardılı olan Cihan Şah Mirza (14381467) döneminde de durum değişmemiş, Rahbe ve çevresindeki bedeviler yol kesmeye ve yağmalamaya devam etmişlerdir. ${ }^{88}$ Yine de bütün bu doğal ve insani afetlere rağmen Rahbe'nin, Orta Çă̆ boyunca müreffeh bir şehir olduğu söylenebilir. Nitekim 10. yüzyıl sonu ile 11. yüzy1lın başına ait olan bazı arkeolojik materyaller ve seramikler, şehirde insan yaşamının savaşlar ya da afetlere rağmen kesintisiz olarak sürdüğünü göstermektedir. ${ }^{89}$

Rahbe'nin dini yapısı ve örgütlenmesine dair kaynaklara oldukça az bilgi yansımıştır. Şehirde ağırlıklı olarak Müslümanlar meskûn olmakla birlikte tüm Orta Çağ İslam şehirlerinde olduğu gibi belli ölçüde gayr-1 müslim nüfus mevcut olmuştur. 11. yüzyıla tarihlenen kayıtlar şehirde bir Yakubî ve Nasturî piskoposluğu olduğuna işaret etmektedir. ${ }^{90}$ Aynı şekilde 12. asırda şehre uğrayan seyyah Tudelalı Benjamin (ö. 1173) Rahbe'de kendi liderleri etrafinda örgütlenmiş yaklaşık 2 bin kişilik bir Yahudi nüfus meskûn olduğunu yazmaktadır. ${ }^{91} \mathrm{Bu}$ dini çeşitlilik ve bir arada yaşama kültürünün son dönemlere kadar devam ettiği söylenebilir. Nitekim 19. Yüzyıl sonlarında bölge şehirlerini tanıtmak için kaleme alınmış bir kitapta Hristiyan bir patriğin burada idarecilik yaptığı belirtilir. ${ }^{92} \mathrm{Bu}$ başlık altında son olarak ilmi faaliyetlerden bahsedecek olursak Orta Çağ boyunca daha çok siyasiaskeri amaçlara hizmet eden bir kale-şehir görünümünde olması Rahbe'den az sayıda meşhur âlimin çıkmasına sebep olmuş olmalıdır. 13. yüzyıl müellifi Yakut elHamevî, Rahbî nisbesiyle şehirdeki bazı âlimlerin adını anmaktadır. ${ }^{33}$ Her şehirde olduğu gibi Rahbe'de de ilmî faaliyetler konusunda kadılar ve kadılık makamı önemli bir yer işgal etmiştir. İbnü’l Esir'in kayıtlarına göre Abbasî halifesi elMüstencid (1160-1170) zamanında kadı İbnü’l Murahham’ı tevkif ettiğinde onun

85 İbnü’l Esir, c. IX, s. 451 (Türkçe terc. XI, s. 227); Musil, s. 343-344; Honigmann, "Rahbe", $\dot{I} A$, IX, s. 603.

86 İbn Kesîr, XIV, s. 451.

87 İbn Tağriberdî, s. 364.

88 Bkz. Ebubekir Tihranî, Kitab-ı Diyarbekiriyye, (Çev. M. Öztürk), Ankara 2014, s. 158.

89 Rousset, s. 247.

90 Musil, s. 342; Honigmann, "Rahbe", $\dot{L}$ A, IX, s. 603.

91 Tudelalı Benjamin, s. 68.

92 Sir Charles Wilson, Handbook For Travellers in Asia Minor, Transcaucasia, Persia, London 1895, s. 299.

93 Yakut el-Hamevî, III, s. 35. Şemseddin Sami de Rahbe'nin çok sayıda meşhur âlimin doğum yeri olduğunu belirtir. Şemseddin Sami, "Rahbetü Mâlik b. Tavk", III, s. 2270. 
Rahbe şehrinde felsefeye dair kitaplarını yaktırmıştır. ${ }^{94}$ Müellif İbn Hallikan da 12. yüzyıl ortalarında ünlü alim ve doktor İbn Hamis el-Cühanî'nin (ö. 1157) Rahbe'de kadılık görevini üstlendiğini belirtir. ${ }^{95}$

\section{Şehrin Mimarisi}

Müslüman coğrafyacıların Yukarı Mezopotamya'da Fırat hattı üzerinde kurulmuş en geniş şehir olarak tasvir ettikleri Rahbe'nin ${ }^{96}$ bu pozisyonundan kaynaklı kendine özgü bir mimari yapısı ortaya çıkmıştır. Ayrıca her Orta Çă̆ şehrinde olduğu gibi Rahbe'nin fiziki ve mimari yapılanması da siyasi gelişmelerden doğrudan etkilenmiştir. Yapılanma süreci, önce Zengiler ve daha sonra Eyyubiler zamanında yoğunlaşır. Arkeolog E. Herzfeld'in (ö. 1948) gözlemlerine göre şehirde günümüze ulaşan en eski inşaat Şirkuh dönemine (1155-1174) tarihlenir. Şehrin topografyasındaki bazı değişiklikler sonucunda çevredeki boş alanlar şehre eklemlenmiş, böylece nüfusun artması eski yapıların tekrar kullanılmasına ve yeni yapıların artmasına olanak sağlamıştır. ${ }^{97}$ İlk kurulduğu dönemde şehrin taylasan* şeklinde olduğu belirtilir.98 Bunun dişında Mukaddesî gibi bazı seyyahların gözlemine göre Rahbe dairevi bir yerleşim planına sahipti. Buna göre şehirdeki evler çöl sınırına doğru genişleyen yarım daire şeklinde uzanıyordu. ${ }^{99}$ (Bk. Resim I)

Miskeveyh'in 939 yılına dair düştüğü bir kayıttan anlaşıldığı kadarıyla bu dönemde şehrin iki ayrı kapısı mevcuttu. ${ }^{100}$ Arkeolojik bulgular, Fırat Nehri'nin sağ yakasındaki alanın Eyyubîler tarafindan ele geçirildiğini ve bu dönemden kalma yaklaşık 15 sit alanının sulama kanallarına bağlanmış olduğunu göstermektedir. Bu durum şehrin arazi ve nüfus olarak giderek büyüdüğüne bu sebeple de ihtiyaçtan doğan bir sulama sistemi kurulduğuna işaret etmektedir. ${ }^{101}$ Rahbe'yi bölgedeki diğer şehirlerden ayıran en önemli mimari hususiyeti kuşkusuz toprak bir tepe üzerinde kale içi kale şeklinde inşa edilmiş korunaklı kalesiydi.102 (Bk. Resim VI) İbnü’l Esir'in kayıtlarına göre Hamdanîlerden Nasrüddevle’nin oğlu Ebu Tağlib, h. 360 (970-971) y1lında şehrin hisarlarını tamir ettirmiştir. ${ }^{103}$ Rahbe kalesinin günümüze ulaşan kalıntıları, yapının Suriye'nin topraklarını doğudan gelen düşmanlara karşı savunmak için tasarlandığına işaret etmektedir. 13. yüzyıl ortalarından itibaren

\footnotetext{
94 İbnül Esir, c. IX, s. 439 (Türkçe terc. XI, s. 214).

95 Ibn Khallikan, I, s. 422.

96 Kudâme İbn Cafer, s. 146; Mustawfî, Nų̈̌hetü'l Kulub, s. 202; Kâtip Çelebi, s. 522.

97 Herzfeld, II, s. 384; Rousset, s. 251.

* Zahidlerin başlarına sardıkları sarığın omuzlar üzerine salınan uç kısmı. Şemseddin Sami, Kamus-ı Türkî, Dersaadet (İstanbul), 1317, s. 916.

98 Herzfeld, II, s. 382; Honigmann, "Rahbe" $\dot{L}$ A, IX, s. 602.

99 Mukaddesî, s. 150, 155; Le Strange, s. 106.

100 Miskeveyh, I, s. 393.

101 Rousset, s. 257.

102 Ebü'l Fida, s. 237; Chesney, s. 251; Hormurzd Rassam, s. 333.

103 İbnü’l Esir, c. VII, s. 313 (Türkçe terc. VIII, s. 512); Musil, s. 341.
} 
giderek artan Moğol saldırıları ile birlikte gelen tahribat şehirdeki savunma yapılarının güçlendirilmesini gerektirince Suriye kaleleri gibi birkaç kez onarılmış, bu vesileyle şehir halkı tarım arazileri dışında inşa edilen yeni bir kaleye çekilmiştir. Günümüze ulaşan kalıntılarda görülen büyük kesme taş işçiliği bu döneme ait olmalıdır. Böylece bu kale ve çevresinde oluşan yeni şehir bu dönem itibariyle Suriye bölgesinin doğu sınırını oluşturmaktaydı. ${ }^{104}$

Kaynaklarda anlatılan hadiseler Rahbe kalesinin, sağlam ve korunaklı olması sebebiyle gözde bir hapishane olarak kullanıldığına işaret etmektedir. Mesela Ukaylî emiri Müslim b. Kureyş’in, tutuklattığ1 Türkleri burada hapsettiği ve onların ölünceye kadar burada kaldıkları belirtilir. Aynı şekilde 1085 yılında Şerefüddevle'nin veziri de burada hapsedilmiş, ancak kaçarak Bağdat'a gelmeyi başarmıştı. 1118 yılında ise Abbasî halifesi Müsterşid, (1118-1135) kendisine rakip olarak gördüğü kardeşi Ebu'l Hüseyn'i bu korunaklı kalede hapsetmeyi tercih etmiştir. ${ }^{105}$ Hapis dişında şehirde bazı durumlarda idam infazlarının gerçekleştirildiği, bu amaçla idam sehpalarının kurulduğu bazı kaynaklarda ifade edilir. ${ }^{106}$ Kale kalıntıları, 17. yüzyılda bu bölgeye gelen J. B. Tavernier'in de dikkatinden kaçmamıştır: "Maşed-raba [Meşhed Rabbe] bir tepe üstünde yer alan bir çeşit bisar; tepenin eteğinde, çöllerde az rastlanacak biçimde bir su örtüsü olusturan bir çeşme bulunuyor. Yükesek surlu, kare biçimli birkaç kuleli hisarın içinde bayvancillkla uğraşan insanlarn oturduğu köhne kulübeler var'107 Tavernier'in betimlediği bu harabe ve metruk görüntü aynı yüzyılın coğrafyacısı Kâtip Çelebi gibi Osmanlı müellifleri tarafından teyit edilir. ${ }^{108}$ Rahbe harabeleri sonraki asırlarda da Batılı oryantalist ve arkeologlar tarafindan ziyaret edilmiştir. 19. yüzyılda bölgeye gelen E. Sachau (ö. 1930), 'Rabbe'yi Meropotamya'dan ilk gördügünüzde bavada asıl bir kalenin büyülü įlenimine kapilyorsunuz" dedikten sonra buranın ateşli silahlar kullanılmadan evvel bu şehrin yenilmez bir kale olduğunu vurgular. Sachau, iç ve diş duvarlarının önemli bir kısmı halen ayakta olan kalenin 250 fit (yaklaşık 75 metre) yüksekte izole bir tepe üzerinde kurulmuş olduğunu yazar. Yap1 malzemesi olarak çok kalın olmayan pişmiş kil tuğladan örülmüştür. (Bk. Resim X) Dış duvarı kare şeklindeki kulelerle güçlendirilmiş, giriş kısmı ise birçok yerinde alt yap1 tonozlarla desteklenmiştir. Sachau, her ne kadar kale kapısının ortadan kaybolmuş olduğunu söylese de kuzey köşesinde olması gerektiğini düşünür. Kalenin batı tarafindaki yüksek bir duvar üzerinde kufi harflerle yazılmış bir yazıt bulunur. Ancak yapının tahrip olmasından dolayı okunamaz durumdadır. Bir diğer doğu bilimci Herzfeld, yazım üslubundan yola çıkarak bu kitabenin Melikşah dönemine veya Nureddin

104 Herzfeld, II, s. 384; Rousset, s. 243.

105 İbnü’l Adim, II, s. 47; İbnü’l Esir, c. VIII, s. 441 (Türkçe terc. X, s. 134); Azimî, s. 50).

106 Bkz. İbnü'l Esir, c. X, s. 89 (Türkçe terc. XI, s. 359).

107 Tavernier, s. 301.

108 Bkz. Kâtip Çelebi, s. 533. Şehri kısa cümlelerle tanımlayan Şemseddin Sami de aynı harabe duruma dikkat çekmiştir. Şemseddin Sami, "Rahbetü Mâlik b. Tavk", III, s. 2270. 
Zengi dönemine ait olduğunu düşünür. ${ }^{109}$ Çağdaş yazarlardan Merie-Odile Rousset, arkeolojik kazılarda elde edilen seramiklerden yola çıkarak Rahbe'deki süsleme sanatının İran süsleme sanatıyla benzeştiğini, dolayısıyla bu ülkeden bazı zanaatkarlar aracılığıyla şehre transfer edilmiş olabileceği ihtimali üzerinde durmaktadır. ${ }^{110}$

\section{Sonuç}

Orta Çă̆'da Rahbe şehri, Firat Nehri’nin takip ettiği güzergâh üzerinde Suriye ile Irak topraklarını birbirinden ayıran sıra dışı bir arazide kurulmuş sağlam yapısıyla ön planda olan bir yerleşim olmuş, özellikle merkeze karşı isyan girişimleri, kuşatmalar ve yağmalar vesilesiyle sıkça gündeme gelmiştir. Irak ve Suriye ülkeleri arasinda kurulmuş olduğu için duruma ve döneme göre bazen Irak'tan gelen saldırılardan Suriye'yi; bazen de Suriye'den gelen saldırilardan Irak topraklarını koruma vazifesi üstlenmiştir. Bu askeri avantajları sebebiyle Rahbe, kaynaklarda genellikle mağlubiyetlerden sonra sığınılan, teçhizat takviyesi yapılan veya zaman kazanılan istihkam şehri olarak zikredilir. Selçuklu hükümdarlarının Haçlılarla mücadele çerçevesinde Musul şehrine vali olarak atadıkları Türk komutanları döneminde Rahbe'nin askeri üs misyonunun daha fazla ön plana çıktı̆̆1 söylenebilir. Coğrafi pozisyonu ve çift duvarla çevrilmiş korunaklı kalesi, bölge üzerinden seyreden ticaret kervanları için de gözde bir durak merkezi olmasını sağlamıştır. Böylece 9. asır ortalarına tarihlenen kuruluşundan başlayıp Orta Çă̆ sonlarına kadar siyasi ve ticari önemini muhafaza eden şehir, Moğol-Memlük savaşlarının sona ermesi ve daha da önemlisi 16. yüzylldan itibaren bölgenin Osmanlı Devleti'nin toprak bütünlüğü altında birleşmesi üzerine eski önem ve değerini hızlı bir şekilde yitirmeye başlamıştır. Bu dönemden itibaren çok yönlü dinamizmini gözle görülür şekilde kaybetmeye başlayan Rahbe, asırlar önceki azametine işaret eden harabeleriyle baş başa kalarak günümüze kadar gelmiştir.

\section{Kaynaklar}

Abdurrahman İbnü’l Cevzî, el-Muntaz̧am fi Taribi'l Ümem'de Selçklular, (Seçme, Tercüme ve Değerlendirme: Ali Sevim), TTK Yayınları, Ankara 2014.

Abu'l Farac Barhabreus, Abu'l Farac Taribi, (Çev. Ö. Riza Doğrul), c. I-II, TTK Yayınları, Ankara 1999.

Ahmed b. Mahmud, Selçuk-nâme, (Haz. Erdoğan Merçil), c. I, Kervan Yayınları, İstanbul 1977.

Aksaraylı Kerimeddin Mahmud, Müsamerat al-Abyar (Selçukî Devletleri Tarihi), (Çev. M. Nuri Gençosman), Ulusoğlu Basımevi, Ankara 1943.

Anonim, Baypars Taribi, (Çev. Şerafeddin Yaltkaya), TTK Yayınları, Ankara 2000.

109 Bkz. Eduard Sachau, Reise in Syrien und Mesopotamien, Leipzig 1883, s. 279-281. Herzfeld, II, s. 384.

110 Rousset, s. 249. 
Ashtor, Eliyahu, A Social and Economic History of the Near East in the Middle Ages, University of California Press, London 1976.

Azimî, Ažimî Taribi (Selçklular Dönemiyle İlgili Bölümler H.430-538=1038/39-1143/44), (Çev. Ali Sevim), TTK Yayınları, Ankara 2006.

Bianquis, Thierry, "Raḥba Et Les Tribus Arabes Avant Les Croisades”, Bulletin D'études Orientales, Institut Francais du Proche-Orient (1989-1990), ss. 23-53.

Chesney, Francis Rawdon, Narrative of The Euphrates Expedition, Carried On By Order of The British Government During The Years 1835, 1836 and 1837, Longmans Green \& Co, London 1868.

Ebubekir Tihranî, Kitab-ı Diyarbekiriyye, (Çev. Mürsel Öztürk), TTK Yayınları, Ankara 2014.

Ebü’l Ferec İbnü’l İbrî, Taribu Mubtasari'd-Düvel, (Çev. Şerafeddin Yaltkaya), TTK Yayınları, Ankara 2011.

Ebü’l Fida, Ebü’l Fida Coğrafyası (Takvimü'l Büldan), (Çev. Ramazan Şeşen), Yeditepe Yayınlar1, İstanbul 2017.

el-Belazurî, Fütubu'l Büldan (Ülkelerin Fetibleri), (Çev. Mustafa Fayda), Siyer Yayınları, İstanbul 2013.

el-Ömerî, Türkler Hakeknda Gördüklerim ve Duyduklarm (Mesalikü'l Ebsar), (Çev. Ahsen Batur), Selenge Yayınları, İstanbul 2014.

Hamdallah Mustawfi, Nuð̧hat-al-Qulub, (İng. Çev. G. Le Strange), E. J. Brill, Leiden 1919. , Tarih-i Güzide, (Çev. Mürsel Öztürk), TTK Yayınları, Ankara 2018.

Herzfeld, Ernst, Archaologische Reise im Euphrat-und Tigris-Gebiet, vol. II, Verlag Von Dietrich Reimer, Berlin 1911.

Honigmann, E., "Rahbe”, İslam Ansiklopedisi, c. IX, MEB. Yayınlar1, İstanbul 1964, ss. 601 604.

Ibn Khallikan, Kitab-ı Vefayatu'l Ayan, (Biographical Dictionary), (İng. çev. M. G. De Slane), vol. I, II, Allen And Co., London, 1843.

Ibn Serapion, "Description of Mesopotamia And Baghdad", (Arapça Metin, İng. çev. ve Notlar Guy Le Strange), Journal of Royal Asiatic Society, London 1895, ss. 1-76.

İbn Battuta Tancî, İbn Battuta Seyahatnâmesi, (Çev. A. Sait Aykut), c. II, Yapı Kredi Yayınları, İstanbul 2004.

İbn Cübeyr, Endülüs'ten Kutsal Topraklara, (Çev. İsmail Güler), Selenge Yayınları, İstanbul 2003.

İbn Haldun, Mukaddime, (Haz. Süleyman Uludağ), c. I, Dergâh Yayınları, İstanbul 2007.

İbn Havkal, 10. Asırda İslam Coğrafyası, (Çev. Ramazan Şeşen), Yeditepe Yayınları, İstanbul 2014.

İbn Hurdazbih, Yollar ve Ülkeler Kitabı, (Çev. Murat Ağarı), Kitabevi Yayınları, İstanbul 2008.

İbn Kesir, el-Bidaye ve'n Nihaye, (Büyü̈ İslam Taribi), (Çev. Mehmet Keskin), c. XI-XIV, Çağrı Yayınları, İstanbul 1995.

İbn Miskeveyh, Tecaribu'l Ümem, (Çev. Kıvameddin Burslan), c. I-II, TTK Yayınları, Ankara 2016.

İbn Tağriberdî, en-Nücumu'z. Zabire, (Parlayan Yuldı‡lar), (Çev. Ahsen Batur), Selenge Yayınları, İstanbul 2013. 
İbn Vâsıl, Müferricü'l-Kurub fi Abbari Beni Eyyub, c. V, (H. Muhammed Rebi-Said Abdulfettah Asur), Kahire, ts.

İbnü'l Adim, Zübdetü' l-Haleb Min Taribi Haleb' de Selçuklular, c. I-II, (Seçme, Tercüme ve Değerlendirme: A. Sevim), TTK Yayınları, Ankara 2014.

İbnü'l Esir, el-Kâmil Fi't Tarih, c. VI-XI, (Neşr. Dr. M. Yusuf Dekak), Daru’l Kutub al İlmiyah, Beyrut 1987; (Türkçe Terc. Abdülkerim Özaydın-Ahmet Ağırakça), c. VIIXI, Bahar Yayınlar1, İstanbul 1986-1987.

İbnü’l Ezrak, Tarih-i Meyyafarikin, (Mervani Kürtleri Taribi), (Çev. M. Emin Bozarslan), c. I, Koral Yayınevi, İstanbul 1990.

İbnü’l Verdî, Bir Ortaçăg Șairinin Kaleminde Selçklular, (Tercüme ve Notlar: Mustafa Alican), Kronik Yayınları, İstanbul 2017.

İbnü’l-Kalanisî, Taribu Dımaşk (360-555), (Neşr. Süheyl Zekkar), Dârü Hassan, Dımaşk 1983. (Türkçe Terc. Hasan Aydın, İbn Kalanisi, Hayat ve Eserleri, "Zeylü Tarih-i Dımaşk." Tercümesi (s. 142-549), Marmara Üniversitesi Türkiyat Araştırmaları Enstitüsü, (Yayımlanmamış Yüksek Lisans Tezi), İstanbul 2016).

Kâtip Çelebi, Cihânnümâ, (Ed. Said Öztürk), İBB Kültür Yayınları, İstanbul 2010.

Kudâme İbn Cafer, Kitabü'l Harac (Fetibler, Siyaset, Coğrafya, Vergiler ve Bürokrasi), (Çev. Ramazan Şeşen), Yeditepe Yayınları, İstanbul 2018.

Le Strange, G., The Lands of Caliphate, Barnes \& Noble Inc., New York 1905.

Minorsky, V. Hududu'l Âlem Mine'l Meşrik İle'l Mağrib, (Çev. Abdullah Duman-Murat Ağarı), Kitabevi Yayınları, İstanbul 2008.

Morton \& Eden, Auction 107, Lot 37 (https://www.numisbids.com/n.php?p=lot\&sid =3764\&lot=37) (Erişim Tarihi: 08-09-2021).

Mukaddesî, İslam Coğrafyası, (Ahsenü't-Tekasim), (Çev. D. Ahsen Batur), Selenge Yayınları, İstanbul 2015.

Musil, Alois, The Middle Euphrates: A Topographical Itinerary, New York 1927.

Öğün Bezer, Gülay, "Müslim b. Kureyş”, Diyanet İslam Ansiklopedisi, c. 32, İstanbul 2006, ss. 94-96.

Polat, Ziya, Umut İadesi: Imâdüiddin Zengî, Hiper Yayın, İstanbul 2019.

Rassam, Hormuzd, Asshur and the Land of Nimrod, Eaton \& Mains, New York 1897.

Rey, E. Gulliame, Etude Sur Les Monuments De L'architecture Militaire Des Croisés En Syrie Et Dans L'île De Chypre, Imprimerie Nationale, Paris 1871.

Rousset, Marie-Odile, "La Ville De Raḥba-Mayādīn Et Sa Région, IX ${ }^{\mathrm{e}-X I V e}$ Siècle”, Bulletin d'études orientales, T. 52, (2000), ss. 243-261.

Sachau, Eduard, Reise in Syrien und Mesopotamien, F. A. Brockhaus, Leipzig 1883.

Sibt İbnül Cevzî, Mir'âtü'z-Zaman fi Taribi'l Ayan (Selçklular Kısmı), (Seçme, Tercüme ve Değerlendirme: Ali Sevim), TTK Yayınları, Ankara 2011.

Stephen Album Rare Coins (Auction 31, 17-19 May 2018) (https://www.stevealbum.com/ pdfs/auc31web.pdf) (Erişim Tarihi 08-09-2021).

Süryani Mihail, Vekayinâme, (Çev. H. D. Andreasyan), (Basılmamış TTK Nüshası), 1944.

Şemseddin Sami, "Rahbetü Mâlik b. Tavk", Kamus al-A'lam, c. III, Mihran Matbaas1, İstanbul 1308 (1891), s. 2270. , Kamus-ı Türkî, İkdam Matbaası, Dersaadet (İstanbul), 1317. 
Tabarî, The History of al-Tabari (Ta'rikh al-rusul wa 'l-muluk), vols. V, XXXVII, XXXVIII (İng. Çev. C. E. Bosworth-Philip M. Fields-Franz Rosenthal), State University of New York Press, New York 1985-1999.

Tavernier, Jean-Baptiste, Tavernier Seyehatnâmesi, (Çev. Teoman Tunçdoğan), Kitap Yayınları, İstanbul 2006.

The Holy Bible, An Extract Reprint Page for Page of the Authorized Version, Oxford University Press., Oxford 1833.

Tudelalı Benjamin-Ratisbonlu Petechia, Ortaçağ'da İki Yahudi Seyyabın İslam Dünyası Gözlemleri, (Çev. Nuh Arslantaş), M. Ü. İlahiyat Fakültesi Vakfı Yayınları, İstanbul 2009.

Wilson, Sir Charles, Handbook For Travellers in Asia Minor, Transcaucasia, Persia, John Murray Albemarle Street, London 1895.

Yakut el-Hamevî, Mu'cemu'l Buldan, c. III, Dar Sader, Beyrut 1977.

Zehebî, Düvelü'l İslam, c. I-II, (Tahkik: Hasan İsmail Merde), Dar Sader, Beyrut 1999. 
EKLER

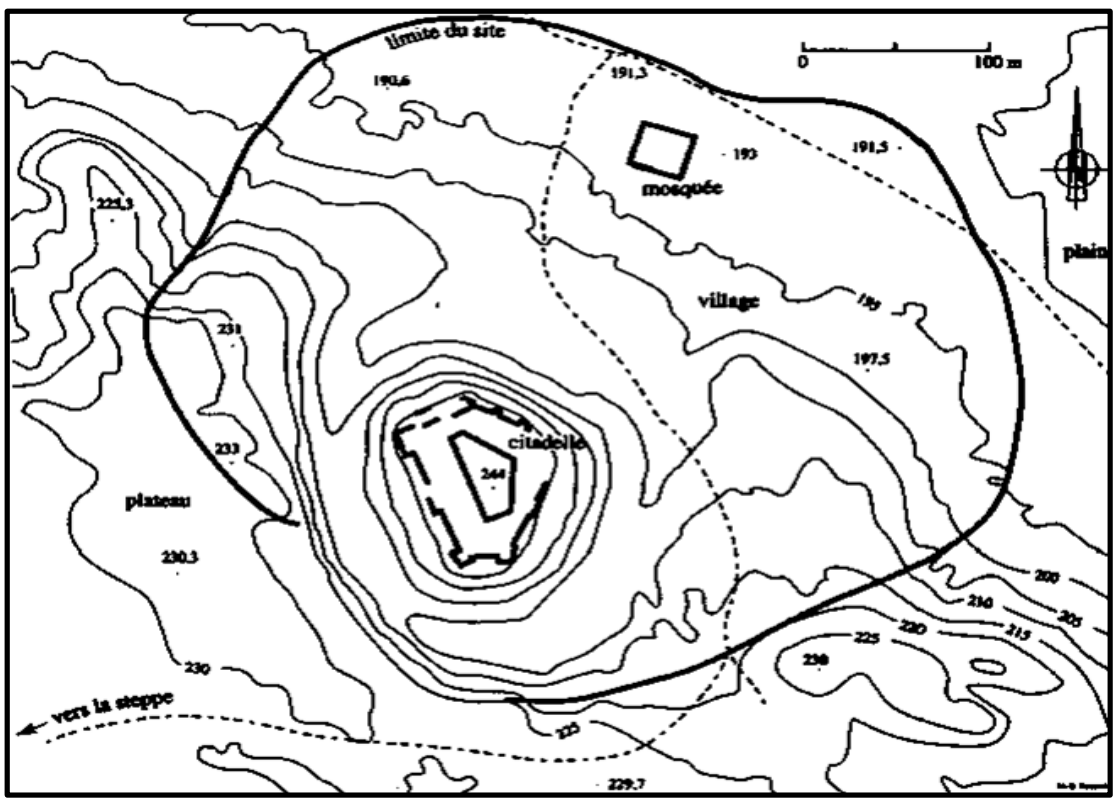

Resim I: Rahbe Şehir Planı (Rousset, s. 252)

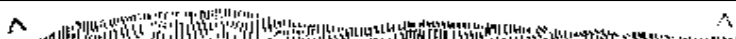

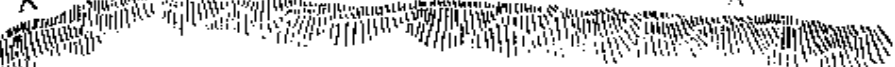

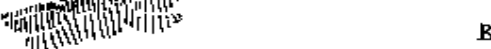

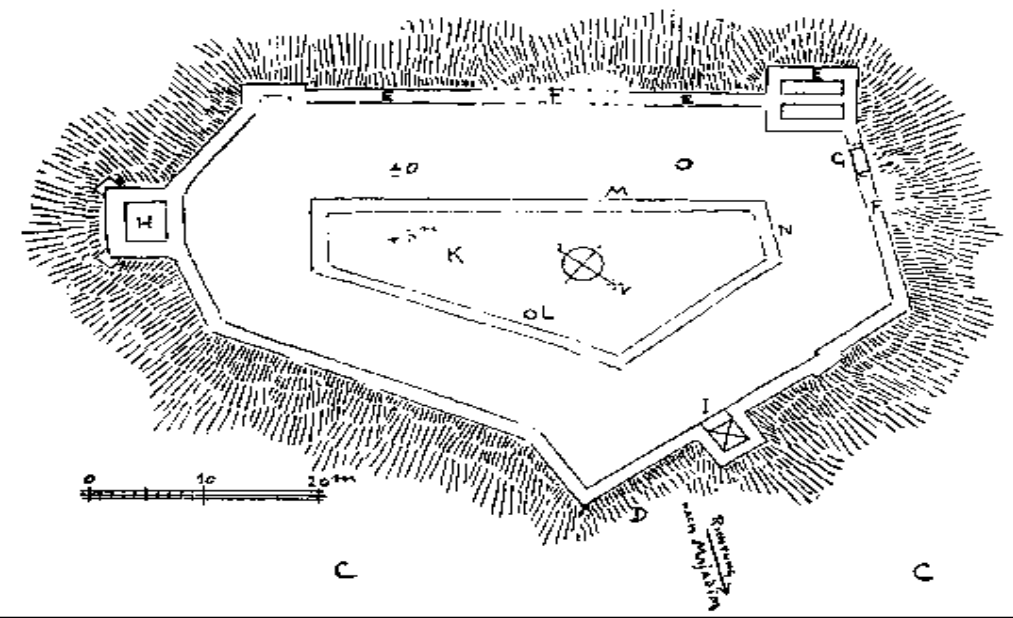

Resim II: Rahbe Kale Yerleşimi (Herzfeld, II, s. 385) 


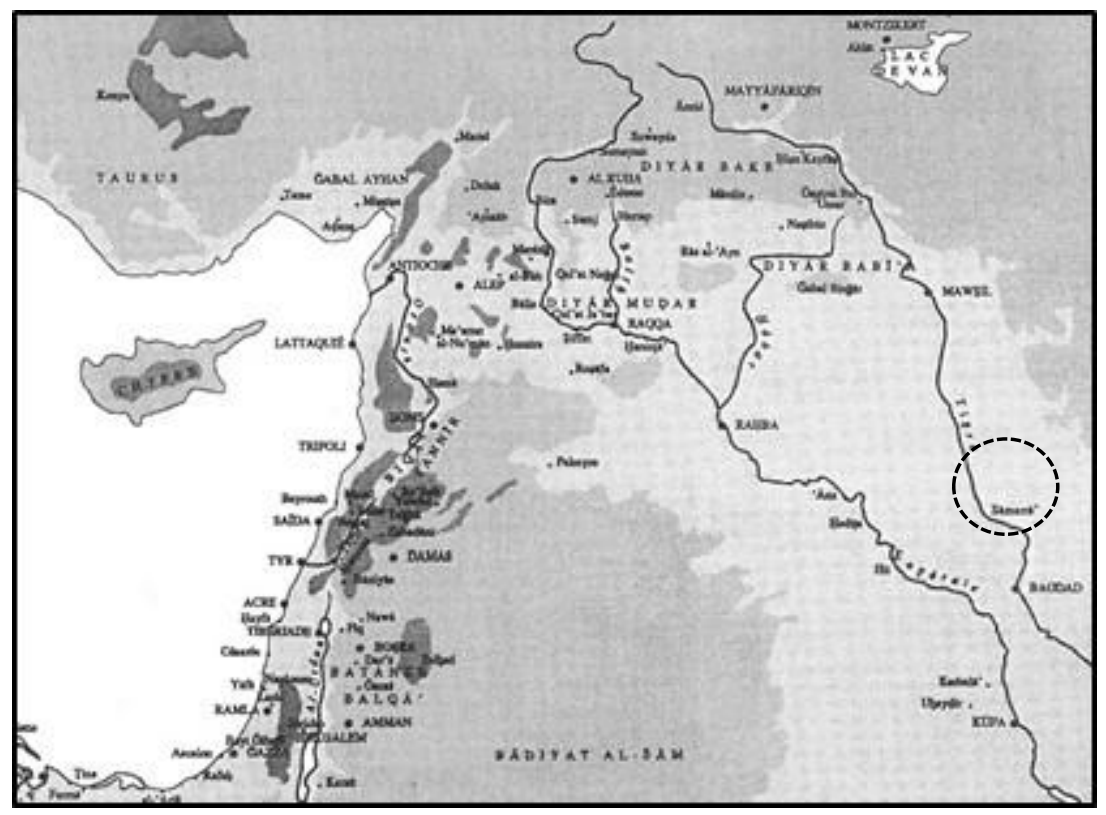

Resim III: Rahbe Şehrinin Suriye-Irak Üzerindeki Konumu (Bianquis, s. 44)

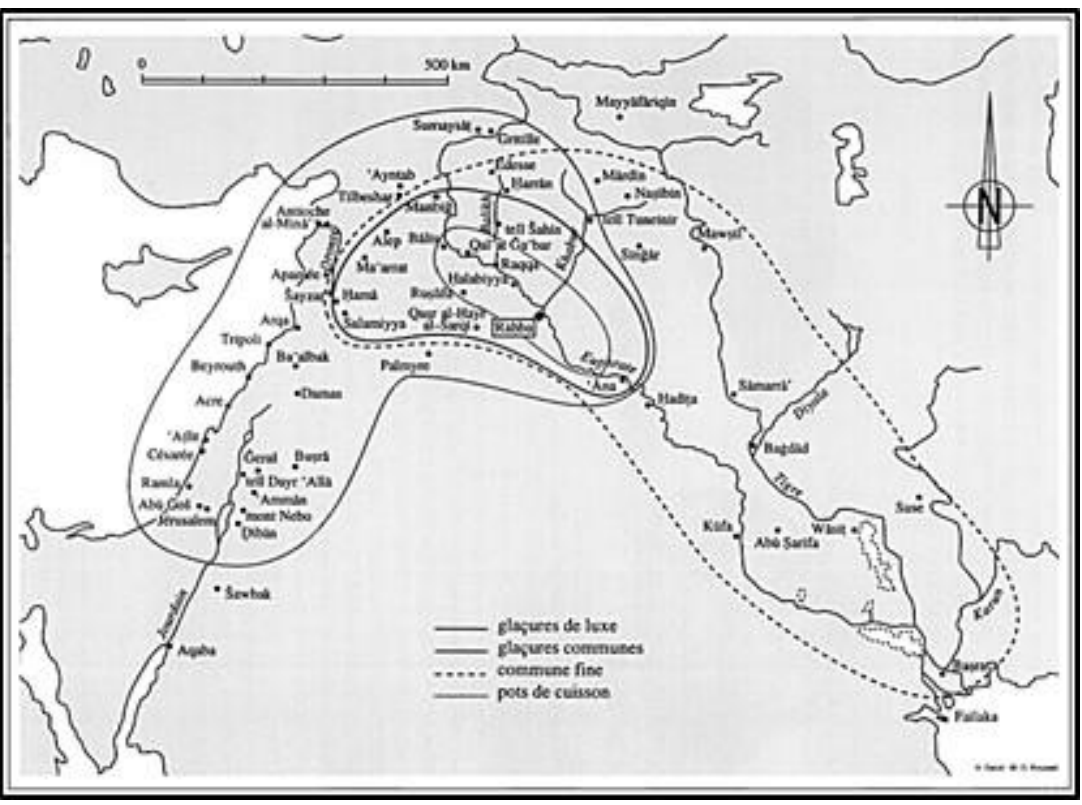

Resim IV: Rahbe'nin Suriye ve Irak arasındaki Konumu (Rousset, s. 250) 


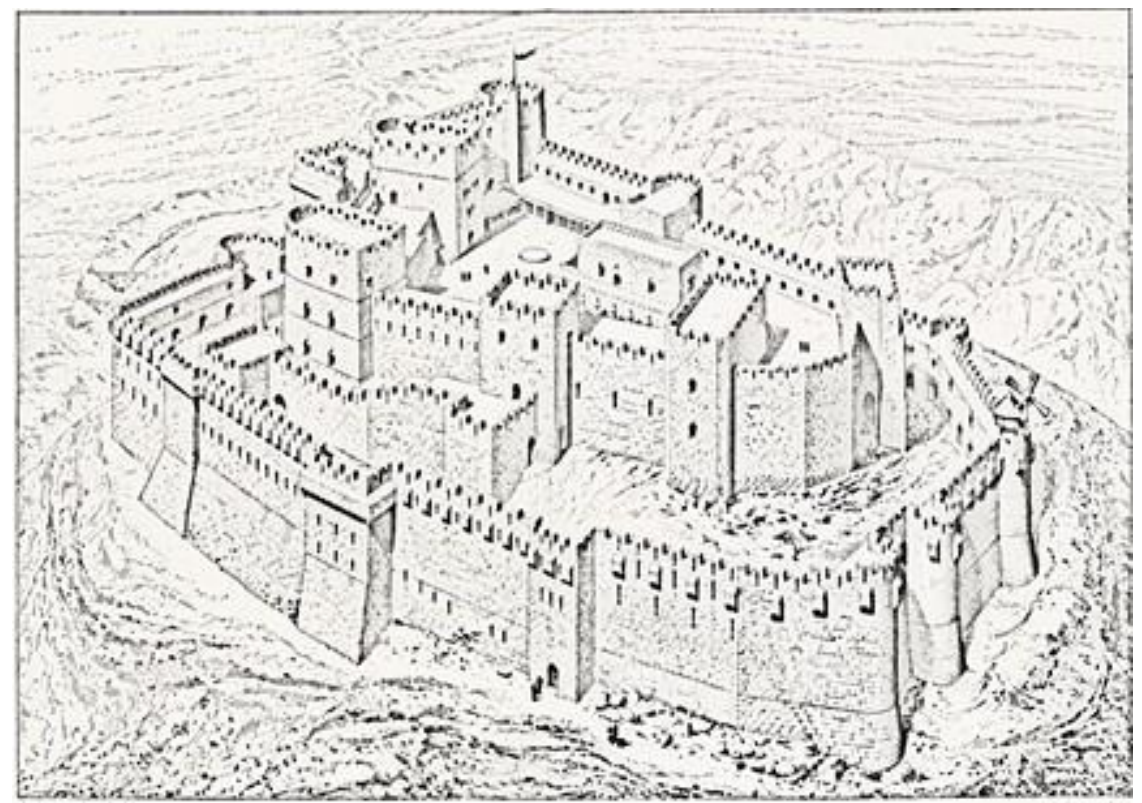

Resim V: Rahbe Kalesinin İnşa Modeli (Temsili) (E. Gulliame Rey)

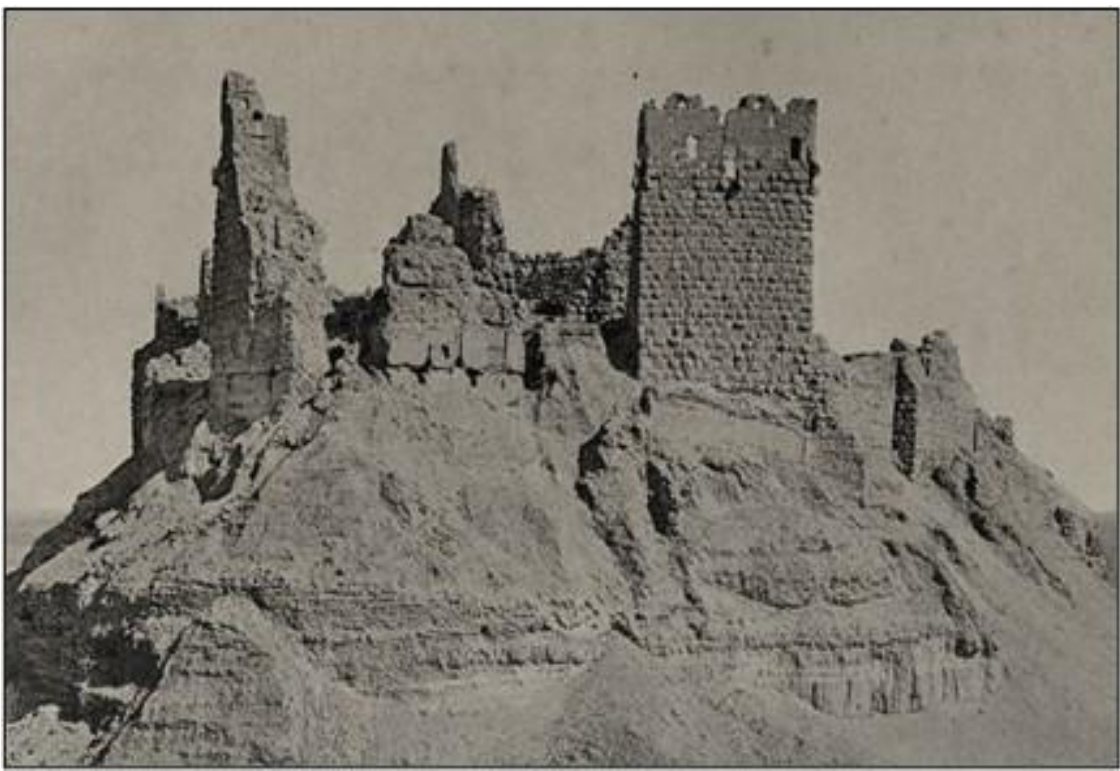

Resim VI: Rahbe Kalesinden Günümüze Kalanlar (Herzfeld, III, Lev. LXXIX) 


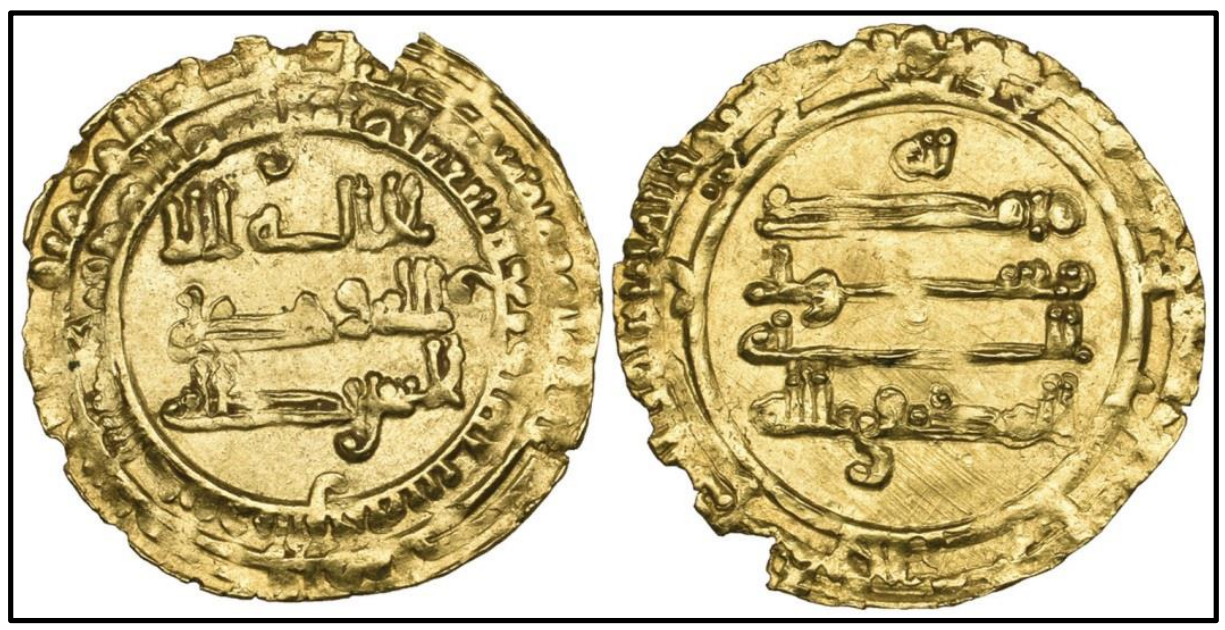

Resim VII: Halife el-Müktefi Zamanında h. 294 (906-907) Yılında Rahbe'de Basılmış Bir Dinar (Morton \& Eden, Auction 107, Lot 37)

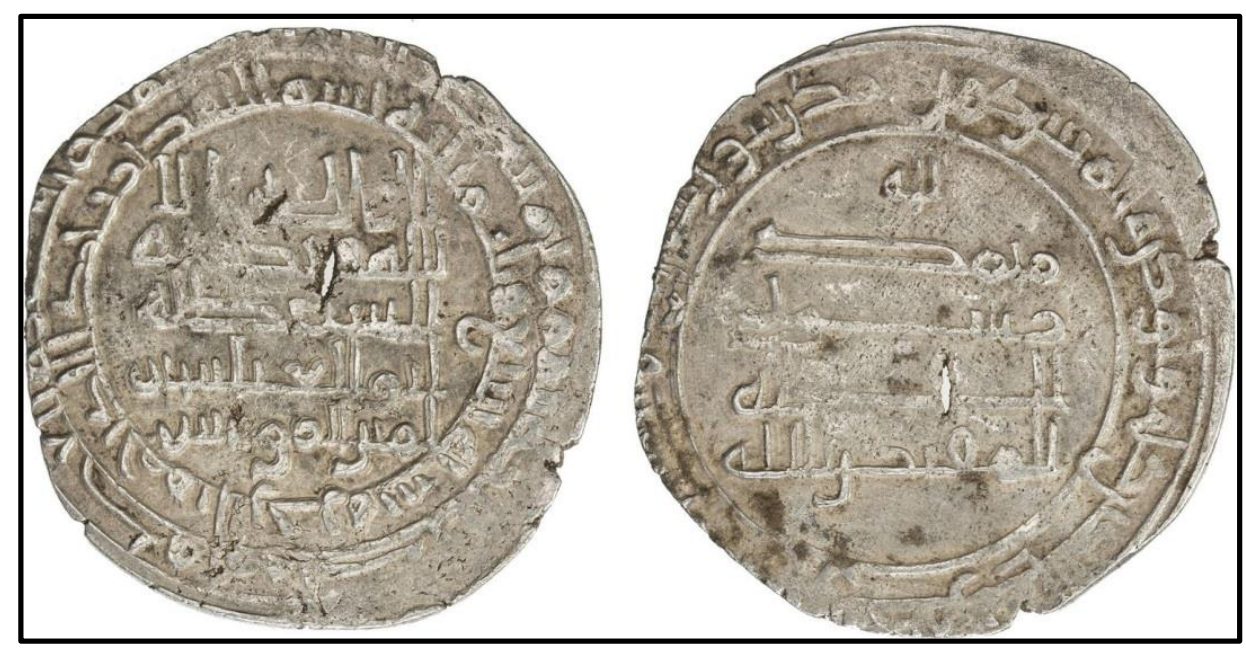

Resim VIII: Halife el-Muktedir Zamanında h. 307 (919-920) Yılında Rahbe'de Basılmış Bir Dirhem (Stephen Album Rare Coins, Auction 31 s. 30) 


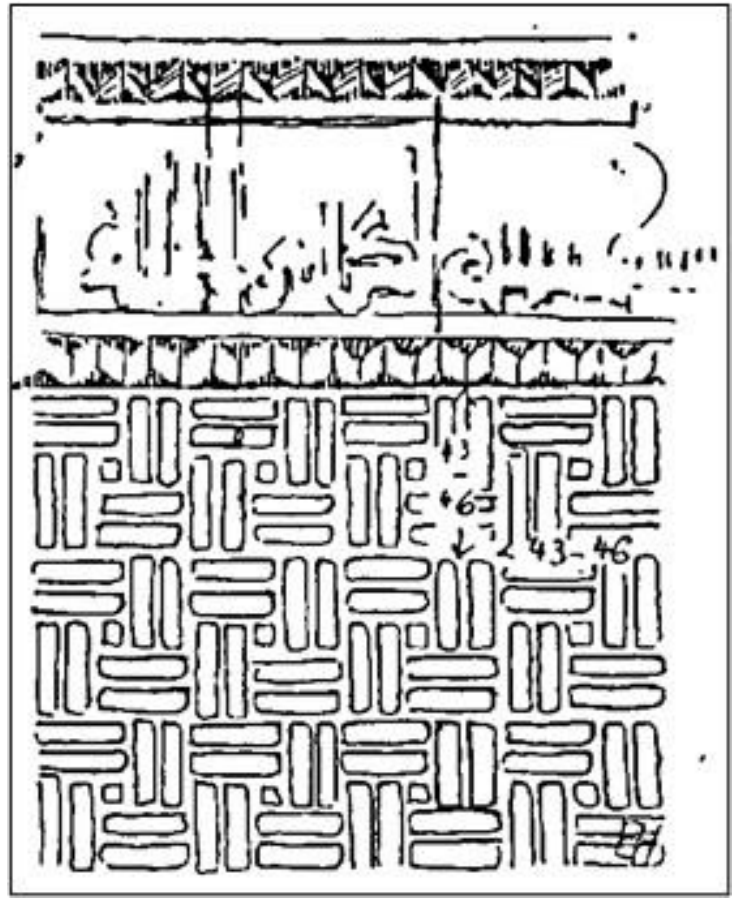

Resim IX: Rahbe Kalesi Duvar Motifi ve Yazıtı (Herzfeld II. s, 383)

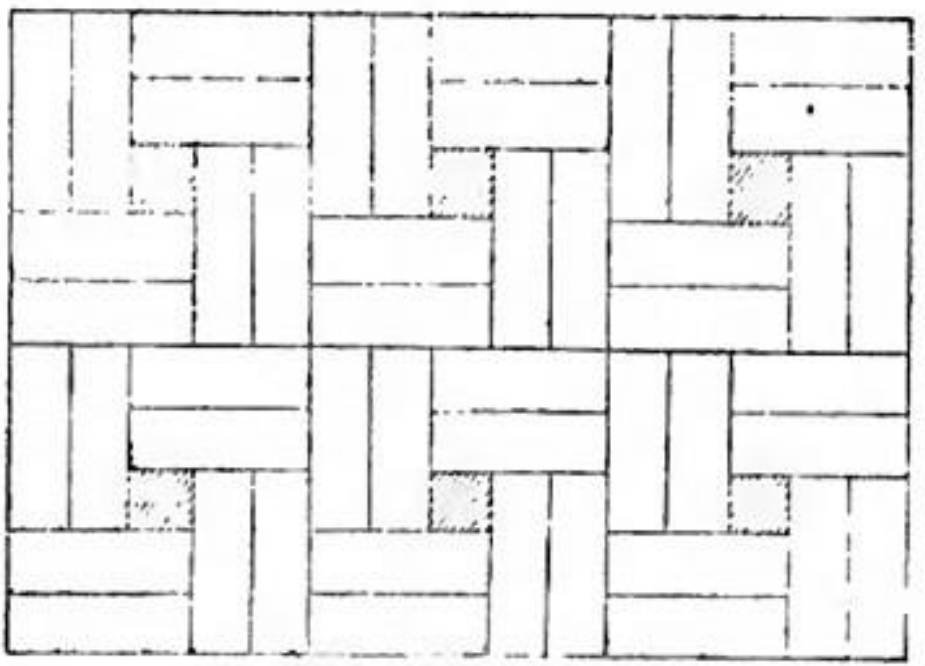

Resim X: Rahbe Kalesi'ndeki Tuğlaların Katmanlanması (Sachau, s. 280) 


\section{Summary}

Rahba is a fortification city founded on the shores of the Euphrates towards the end of the $9^{\text {th }}$ century. Founding of the city is attributed to Mâlik b. Tawk al-Taghlibî, one of the commanders of Ma'mun. The city is located on the western border of Iraq and the eastern border of Syria. This geographical location allowed the city to retain its military and political importance throughout the Middle Ages. In addition, due to the fact that one side is surrounded by a river and the other side is surrounded by desert, Rahba has a natural obstacle against external dangers. Thus, it became a sheltered city that was easy to defend.

There are various rumors about the meaning and origin of the name of the city. In some sources, it is said that this word matches the names in the Talmud. In Arabic sources, it usually states that the word means "square" (meydan; pl. mayadin). The fact that the ruins of the city that have survived to the present day are located in the Mayadin in Syria makes this possibility strong.

Rahba has had a position in connection with both Syria and Iraq due to the geography of its establishment. For this reason, there are disputes among medieval authors as to whether the city was included in Syria or Iraq. The fortified structure of the city has made it one of the favorite places not only for rulers and commanders, but also for rebellious individuals or groups. It is stated in the sources that the Qarmatians, who were active in Syria in the 10th century, captured and plundered this city. In the following times, it was also the place of some bandits who rebelled against the Abbasid rule. From time to time, the city was dominated by the local dynasties that were affiliated with Abbasids or Fatimids.

Rahba was under the control of the Fatimids in the early $11^{\text {th }}$ century and served as one of the outposts on their eastern border. In the middle of this century, after the Seljuks seized Iraq, it became a strategic outpost that closely felt the Sunni-Shiite conflict. When Toghril Beg came to Baghdad in 1055, Arslan Besasirî, who escaped from him, took refuge in this fortified castle and called for help from the Fatimid caliph. In later periods, when it was included in the Seljuk borders, the Seljukid rulers generally left the management of the city to the local rulers. In the following centuries, the city kept up with the political activity in the region and it remained a sheltered and strategic fortress city throughout the Middle Ages.

In 1093 the city was temporarily under the rule of Tadj ad-dawla Tutush, brother of Malik-shah. After he was destroyed during the struggle for the sultanate, it changed hands for a while in the hands of several Seljukid commanders. In 1104 Rahba was under the rule of Dukak, son of Tutush. After 1107, it came into prominence as an operation center and refuge of Mawsil governors of Seljuks. The governors of Mawsil such as Aksunkur alBursiki, Djawali, Djokermish, Mawdud and Zangi regarded as the city an important base in the fight against the crusaders. After gaining considerable control over Syria, Nur al-din, (the son of Zangi) left the administration of Rahba to Shirkuh (Salahaddin's uncle) in 1164. The Shirkuh family managed 
to hold the city for a whole century until Sultan Baypars captured the city in 1264.

The city witnessed the violence of the conflicts between the Mongols, who dominated Iraq, and the Mamluks, who held Syria, especially in the middle of the $13^{\text {th }}$ century. During the Mamluk rule, Rahba served as a strong and reliable fortress city against the Mongol invasion. It was besieged and subjected to violent attacks especially during the Mongolian ruler Gazan Khan. After the end of the Mongol threat at the beginning of the 14th century, Rahba castle began to lose its importance and the fortress was gradually evacuated by Mamluk forces as it was costly to maintain. From this date forward the name Rahba is rarely mentioned on occasion of some political struggles of local dynasties in the region. The city, which quickly became insignificant with the beginning of the Ottoman rule, has survived to the present day with a few ruins. These ruins have not escaped the attention of western travelers visiting the region since the 17th century. Within this framework, at various times, travelers or archaeologists such as Jean-Baptiste Tavernier (d. 1689), Edward Sachau (d. 1930) and Ernst Herzfeld (d. 1948) visited the ruins and conveyed their observations. 